\title{
The Adaptor Protein CD2AP Is a Coordinator of Neurotrophin Signaling-Mediated Axon Arbor Plasticity
}

\author{
Benjamin J. Harrison, ${ }^{1,2,3}$ Gayathri Venkat, ${ }^{1,2}$ James L. Lamb, ${ }^{4}$ Tom H. Hutson, ${ }^{5}$ Cassa Drury, ${ }^{6}$ Kristofer K. Rau, \\ Mary Barlett Bunge, ${ }^{8,9}$ Lorne M. Mendell, ${ }^{9,10}$ @Fred H. Gage, ${ }^{9,11}$ Richard D. Johnson, ${ }^{12,13}$ Caitlin E. Hill, ${ }^{14,15}$ \\ Eric C. Rouchka, ${ }^{3,16}$-Lawrence D.F. Moon, ${ }^{5}$ and ${ }^{-J e f f r e y ~ C . ~ P e t r u s k a ~}{ }^{1,2,17}$ \\ ${ }^{1}$ Anatomical Sciences and Neurobiology, University of Louisville, Louisville, Kentucky 40202, ${ }^{2}$ Kentucky Spinal Cord Injury Research Center, University of \\ Louisville, Louisville, Kentucky 40292, ${ }^{3}$ Kentucky Biomedical Research Infrastructure Network, University of Louisville, Louisville, Kentucky 40292, \\ ${ }^{4}$ University of Louisville School of Medicine, Louisville, Kentucky 40292, ${ }^{5}$ Wolfson Centre for Age Related Diseases, King's College, London SE1 1UL, United \\ Kingdom, ${ }^{6}$ DuPont Manual High School, Louisville, Kentucky 40205, ${ }^{7}$ Anesthesiology and Perioperative Medicine, University of Louisville, Louisville, \\ Kentucky 40202, ${ }^{8}$ Miami Project to Cure Paralysis, Department of Neurological Surgery and Neurology, University of Miami Miller School of Medicine, \\ Miami, Florida 33136, ${ }^{9}$ Christopher and Dana Reeve Foundation International Consortium on Spinal Cord Injury Research, Short Hills, New Jersey 07078, \\ ${ }^{10}$ Department of Neurobiology and Behavior, State University of New York at Stony Brook, Stony Brook, New York 11794, ${ }^{11}$ Laboratory of Genetics, The \\ Salk Institute, La Jolla, California 92037, ${ }^{12}$ Department of Physiological Sciences, University of Florida, Gainesville, Florida 32210, ${ }^{13}$ McKnight Brain \\ Institute at the University of Florida, Gainesville, Florida 32611, ${ }^{14}$ Feil Family Burke Medical Research Institute, White Plains, New York 40605, ${ }^{15}$ Brain and \\ Mind Research Institute, Weill Cornell Medical College, New York, New York 40065, ${ }^{16}$ Department of Computer Engineering and Computer Science, \\ University of Louisville, Louisville, Kentucky 40292, and ${ }^{17}$ Department of Neurosurgery, University of Louisville, Louisville, Kentucky 40202
}

Growth of intact axons of noninjured neurons, often termed collateral sprouting, contributes to both adaptive and pathological plasticity in the adult nervous system, but the intracellular factors controlling this growth are largely unknown. An automated functional assay of genes regulated in sensory neurons from the rat in vivo spared dermatome model of collateral sprouting identified the adaptor protein $\mathrm{CD} 2$-associated protein (CD2AP; human CMS) as a positive regulator of axon growth. In non-neuronal cells, CD2AP, like other adaptor proteins, functions to selectively control the spatial/temporal assembly of multiprotein complexes that transmit intracellular signals. Although CD2AP polymorphisms are associated with increased risk of late-onset Alzheimer's disease, its role in axon growth is unknown. Assessments of neurite arbor structure in vitro revealed CD2AP overexpression, and siRNA-mediated knockdown, modulated (1) neurite length, (2) neurite complexity, and (3) growth cone filopodia number, in accordance with CD2AP expression levels. We show, for the first time, that CD2AP forms a novel multiprotein complex with the NGF receptor TrkA and the PI3K regulatory subunit p85, with the degree of TrkA:p85 association positively regulated by CD2AP levels. CD2AP also regulates NGF signaling through AKT, but not ERK, and regulates long-range signaling though $\mathrm{TrkA}^{+} / \mathrm{RAB}^{+}$signaling endosomes. $\mathrm{CD} 2 \mathrm{AP} \mathrm{mRNA}$ and protein levels were increased in neurons during collateral sprouting but decreased following injury, suggesting that, although typically considered together, these two adult axonal growth processes are fundamentally different. These data position CD2AP as a major intracellular signaling molecule coordinating NGF signaling to regulate collateral sprouting and structural plasticity of intact adult axons.

Key words: collateral sprouting; nerve growth factor; neural plasticity; signalosome; spared dermatome; transcriptomics

\section{Significance Statement}

Growth of noninjured axons in the adult nervous system contributes to adaptive and maladaptive plasticity, and dysfunction of this process may contribute to neurologic pathologies. Functional screening of genes regulated during growth of noninjured axons revealed CD2AP as a positive regulator of axon outgrowth. A novel association of CD2AP with TrkA and p85 suggests a distinct intracellular signaling pathway regulating growth of noninjured axons. This may also represent a novel mechanism of generating specificity in multifunctional NGF signaling. Divergent regulation of CD2AP in different axon growth conditions suggests that separate mechanisms exist for different modes of axon growth. CD2AP is the first signaling molecule associated with adult sensory axonal collateral sprouting, and this association may offer new insights for NGF/TrkA-related Alzheimer's disease mechanisms. 


\section{Introduction}

Plasticity of cellular structure is a fundamental biological process. In neurons, structural plasticity occurs in the dendrites, dendritic spines, axons, and axon terminal arbors. Significant advances have been made in understanding the mechanisms underlying structural plasticity of dendrites and dendritic spines, and identifying adaptive/homeostatic neural processes and disease states in which these mechanisms are involved (e.g., Tavosanis, 2012). On the axonal side, much effort has been directed toward understanding the mechanisms regulating the guidance/pathfinding of axons during development or during regeneration (or failure thereof) of damaged axons in the adult (Fagoe et al., 2014; Mar et al., 2014; e.g., Eva and Fawcett, 2014; Doron-Mandel et al., 2015), but the neuron-intrinsic signaling components that regulate structural plasticity of noninjured axon arbors in the adult nervous system remain undefined.

Structural rearrangement of axonal arbors is required for diverse adaptive functions both within the adult nervous system and in its interaction with the periphery (Diamond et al., 1992; Kawabuchi et al., 1995; Hsieh et al., 1996; Botchkarev et al., 1997; Li et al., 1997; Hsieh and Lin, 1999; Selim et al., 2007; Calinescu et al., 2011; e.g., Yasuda et al., 2011; Ibrahim et al., 2013; GonzalezFreire et al., 2014). These same processes contribute to pathologies, such as Alzheimer's disease (Wu et al., 2014), sudden cardiac death (for review, see Vaseghi and Shivkumar, 2008), autonomic dysreflexia after spinal cord injury (Krenz et al., 1999; Marsh et al., 2002; Wanigasekara and Keast, 2006), and exacerbation of epilepsy (Noebels, 1984; Davenport et al., 1990; Van der Zee et al., 1995; Adams et al., 1997; Scharfman et al., 1999; Pitkänen and Sutula, 2002; Sierra et al., 2015). Hyperinnervation of visceral tissue and bone is a characteristic of some of the most agonizing forms of pain (Woolf, 1996; Jimenez-Andrade et al., 2010, 2011, Bloom et al., 2011; López-Álvarez et al., 2015). In addition, although long-distance regeneration of damaged axons rarely occurs after brain or spinal cord injuries or stroke, there is often some degree of spontaneous recovery (e.g., Fawcett et al., 2007), which in part is mediated by short-distance restructuring of CNS axons (e.g., Rosenzweig et al., 2010). Identifying the mechanisms controlling axon plasticity of noninjured neurons could lead to new approaches to enhance recovery from disease and disability.

Although neural activity and extracellular trophic factors are necessary, sufficient, and/or modulatory for axonal arbor restructuring, the intracellular pathways transducing these factors and the cellular processes involved are largely unknown. We used the spared dermatome model of sensory neuron collateral sprouting (Diamond et al., 1992) to identify genes related to axonal plasticity of noninjured neurons in vivo. In this model, de-

Received June 24, 2015; revised Feb. 5, 2016; accepted Feb. 14, 2016.

Author contributions: B.J.H., G.V., T.H.H., C.E.H., K.K.R., M.B.B., L.M.M., F.H.G., R.D.J., E.C.R., L.D.F.M., and J.C.P. designed research; B.J.H., G.V., J.L.L., T.H.H., C.D., C.E.H., K.K.R., E.C.R., and L.D.F.M. performed research; E.C.R. contributed unpublished reagents/analytic tools; B.J.H., G.V., J.L.L., T.H.H., C.E.H., E.C.R., L.D.F.M., and J.C.P. analyzed data; B.J.H., C.E.H., L.D.F.M., and J.C.P. wrote the paper.

This work was supported by the CDRF International Consortium on Spinal Cord Injury Research to M.B.B., L.M.M., and F.H.G., Kentucky Spinal Cord and Head Injury Research Trust Grant 09-12A to J.C.P., Paralyzed Veterans of America Fellowship to B.J.H., National Institutes of Health Grants P20RR016481 to E.C.R., 3P20RR016481-09S1 and P20GM103436 to E.C.R. and B.J.H., P30GM103507 to supporting Core staff and facilities of the Kentucky Spinal Cord Injury Research Center, and R21NS080091, R21NS071299, and R01NS094741 to J.C.P. The article contents are solely the responsibility of the authors and do not represent the official views of the funding organizations, which were entirely uninvolved in the data generation or manuscript preparation.

The authors declare no competing financial interests.

Correspondence should be addressed to Dr. Jeffrey C. Petruska, University of Louisville, 511S. Floyd St. Louisville, KY 40202. E-mail: j.petruska@louisville.edu.

DOI:10.1523/JNEUROSCI.2423-15.2016

Copyright $\odot 2016$ the authors $\quad 0270-6474 / 16 / 364260-17 \$ 15.00 / 0$ nervated skin increases its production of NGF and axons in the adjacent dermatome grow to reinnervate the denervated region in an NGF-dependent manner. Importantly, this model stimulates sensory neurons to undergo axonal arbor remodeling without their injury/disruption, so it can be used to study the molecular mechanisms of axon arbor dynamics independent of injury-induced intracellular signaling.

Analysis of transcriptomic profiles of DRGs in the spared dermatome model published in a separate manuscript (Harrison et al., 2015) revealed upregulation of the adaptor/scaffolding protein CD2-associated protein (CD2AP; CMS in human) (Kirsch et al., 1999). Adaptor proteins selectively control the spatial and temporal assembly of multiprotein intracellular signaling complexes. Although not well studied in the nervous system, CD2AP has a regulatory role in trophic factor-dependent survival of some neurons (Tsui and Pierchala, 2008). In other tissues, CD2AP coordinates actin dynamics, trophic factor receptor internalization, signal transduction, and endosomal sorting (Table 1) (Dustin et al., 1998; Cormont et al., 2003; Huber et al., 2003; Lynch et al., 2003; Kobayashi et al., 2004; Welsch et al., 2005; Tossidou et al., 2007; Johnson et al., 2008; Tsui and Pierchala, 2008; Yaddanapudi et al., 2011; Tang and Brieher, 2013; Zhao et al., 2013), all processes that are predicted to occur during expansion of axon arbors. In the spared dermatome model of plasticity, NGF currently is the only known regulatory factor (Diamond et al., 1992). Although various models of axonal arbor plasticity involve trophic factors (e.g., Scharfman et al., 1999; Zhou et al., 2004; Chen et al., 2006; Iarikov et al., 2007; Prince et al., 2009), the signaling can differ by condition and cell type, and it is often unclear how any specificity arises. We sought to determine whether CD2AP might act to influence NGF:TrkA signaling and axon arbor dynamics.

\section{Materials and Methods}

Materials. All chemicals and reagents were obtained from Sigma-Aldrich unless otherwise stated. Ultra-pure biochemistry-grade chemicals were used whenever possible.

Animals. All animal procedures were approved by the Institutional Animal Care and Use Committee of the State University of New York at Stony Brook and the University of Louisville consistent with federal regulations and guidelines. All rats were female Sprague Dawley 160-200 g. Mice were C57B/6 male 20-30 g.

Assessment of transcription profiles of genes regulated in DRG during sensory arbor expansion. It is currently unclear the degree to which axonal regeneration after nerve injury and arbor expansion of noninjured neurons share intracellular mechanisms. It was therefore desirable to use a model enriched for noninjured adult neurons undergoing axon growth, and depleted of neurons undergoing any other type of axon growth (e.g., injury-induced regeneration, integration of newly generated neurons, etc.). The thoracic and upper lumbar segments provide an advantageous model to study plasticity of noninjured afferents because their nerves have no plexus (Ygge, 1984; Baron et al., 1995). The spared dermatome model of cutaneous afferent sprouting applied to this region reduces the presence of injured neurons in the DRG, which might otherwise dilute the arbor expansion-associated transcript pool with injury/regenerationassociated transcripts. In this model, adapted from (Diamond et al., 1992), one nerve is spared and the two adjacent nerves on either side are transected (Fig. $1 A-D$ ). The axons of the interposed spared nerve subsequently undergo terminal arbor expansion into the adjacent skin that had lost its innervation (denervated dermatomes).

Details of the procedures used to generate the transcriptomic profile from microarray assessments, and the microarray data, are published previously (Harrison et al., 2015). The procedures used for the molecular assessments presented here are identical to those used for the microarray study (Harrison et al., 2015). Briefly, adult Sprague Dawley rats (160-200 g) were anesthetized with $60 \mathrm{mg} / \mathrm{kg}$ pentobarbital. All left-side thoracic 
Table 1. Known CD2AP functions documented in non-neuronal cells that could play a role in axon arbor extension

\begin{tabular}{|c|c|c|}
\hline Biochemical function & Tissue/cells & Physiological role \\
\hline \multirow[t]{4}{*}{ Actin dynamics } & Immortalized mouse podocytes (Yaddanapudi et al., 2011; Zhao et al., 2013) & $\begin{array}{l}\text { Slit diaphragm integrity } \\
\text { Cell motility } \\
\text { Cell differentiation/spreading } \\
\text { Lamellipodia formation }\end{array}$ \\
\hline & Jurkat T-cells (Dustin et al., 1998) & Antigen recognition at the immune synapse \\
\hline & MDCK cell monolayers (Tang and Brieher, 2013) & $\begin{array}{l}\text { Adherens junction integrity } \\
\text { Monolayer resistance to mechanical stress } \\
\text { Epithelial membrane integrity }\end{array}$ \\
\hline & Drosophila melanogaster retinas (Johnson et al., 2008) & Tissue patterning \\
\hline \multirow[t]{5}{*}{ Signal transduction } & Cultured postnatal (P1) sympathetic neurons (Tsui and Pierchala, 2008) & $\begin{array}{l}\text { Neuron survival } \\
\text { Ligand-dependent ubiquitination of RET51 upon GDNF stimulation } \\
\text { Direct binding to RET51 }\end{array}$ \\
\hline & Immortalized mouse podocytes (Tossidou et al., 2007) & $\begin{array}{l}\text { Growth factor signaling } \\
\text { CD2AP enhances PI3K/AKT signaling: FGF, VEGF } \\
\text { CD2AP enhances ERK1/2 signaling: FGF, VEGF, IGF-1, EGF, PDGF }\end{array}$ \\
\hline & NIH3T3 cells (Kobayashi et al., 2004) & $\begin{array}{l}\text { VEGF signaling } \\
\text { Interaction with VEGFR1, bridged by c-Cbl } \\
\text { Receptor internalization }\end{array}$ \\
\hline & HEK293T cells (Huber et al., 2003) & $\begin{array}{l}\text { Protection from anoikis } \\
\text { Direct binding to } \mathrm{p} 85 \\
\text { Positive regulation of AKT pathway }\end{array}$ \\
\hline & MDA-MB-231 cells and HeLa cells (Lynch et al., 2003) & $\begin{array}{l}\text { Formation of membrane ruffles following EGF stimulation } \\
\text { Interaction with EGFR, bridged by } \mathrm{c}-\mathrm{Cbl}\end{array}$ \\
\hline Endosome traffic & $\begin{array}{l}\text { CHO cells (Cormont et al., 2003) } \\
\text { Immortalized mouse podocytes (Welsch et al., 2005) }\end{array}$ & $\begin{array}{l}\text { Endocytosis } \\
\text { Endosome sorting }\end{array}$ \\
\hline
\end{tabular}
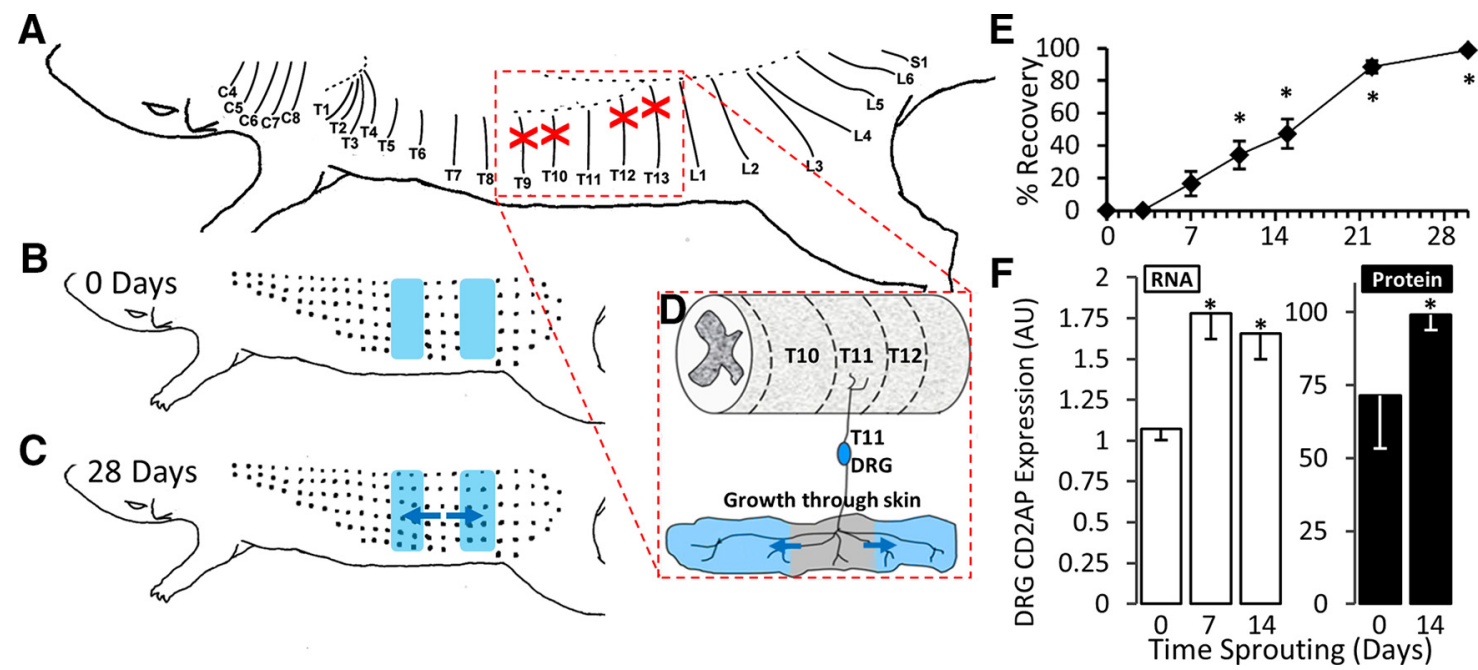

Figure 1. CD2AP is upregulated during sensory arbor expansion in the spared dermatome model. $A, T 9, T 10, T 12$, and $T 13$ DCNs were transected and the proximal cut-end ligated to prevent regeneration (red crosses). $\boldsymbol{B}$, Denervated zones (shaded blue in $\boldsymbol{B}-\boldsymbol{D}$ ) were mapped by pinching the skin with fine forceps to drive the CTMR. $\boldsymbol{B}, \boldsymbol{C}$, Black dots indicate responsive sites. $\boldsymbol{C}$, Arbor expansion proceeds from the spared fibers into the denervated zones. Blue arrows indicate direction of arbor expansion. $\boldsymbol{D}$, Dermatome-focused (segmental) schematic of arbor expansion of cutaneous projections from the T11 DRG. Growth is in the direction of the blue arrows and proceeds into the denervated zones (shaded blue). $\boldsymbol{E}$, Time course of arbor expansion determined using the CTMR. Size of the denervated zones is recorded at time 0 (baseline) until complete reinnervation. Reinnervation of the entire denervated area takes $\sim 28 \mathrm{~d}$. * Significantly changed from day 0 (repeated-measures ANOVA, post hoc Tukey HSD). $\boldsymbol{F}$, Expression of CD2AP mRNA (measured by qPCR) and protein (measured by Western blot) during key stages of arbor expansion. For mRNA, the control is set to a value of 1 . For protein, the strongest signal was set to a value of $100.7 \mathrm{~d}$, Initiation; $14 \mathrm{~d}$, maintenance. * Statistically significant changes from $0 \mathrm{~d}$ (naive) (ANOVA followed by post hoct test).

(T) ninth through 13th dorsal and lateral cutaneous nerves, except T11 (i.e., T9, T10, T12, T13 D/LCnn) were cut and then ligated with fine suture to prevent regeneration. The skin wound (made to the right of midline so as not to injure axons in the left-side T11 skin) (Hill et al., 2010) was then closed with $4-0$ suture and surgical staples. The T11 dermatome was unperturbed and bordered by adjacent denervated skin, and no damage was done to any of the spinal roots. Sensory arbors expand from intact dermatomes into the denervated skin to restore sensation (Fig. 1C,D).

To define the innervated and denervated areas of skin, we used the cutaneous trunci muscle reflex (CTMR) (Petruska et al., 2014) as was done previously (Diamond et al., 1992). The CTMR is a puckering of the back skin in response to noxious stimulation (e.g., heat or pinch) and can be used to report on the sensory innervation status of the skin. The area of innervated and denervated skin was mapped acutely after spared dermatome surgery; and from this baseline, we measured the extent of arbor expansion over time (Fig. 1E). After 7 or $14 \mathrm{~d}$, time points corresponding approximately to the initiation (7 d) and maintenance (14 d) phases of sensory arbor expansion (Diamond et al., 1992), animals were killed by overdose of pentobarbital anesthesia and exsanguinated by intracardial perfusion of cold PBS. DRGs were then retrieved and processed for mi- 
croarray assessment as described previously (Harrison et al., 2015). The three groups were naive $(n=4), 7 \mathrm{~d}$ after spared-dermatome surgery $(n=8)$, and $14 \mathrm{~d}$ after spared-dermatome surgery $(n=10)$. Neither analyses of raw microarray image data (Harrison et al., 2015) nor the molecular data presented here were adjusted for possible influence of estrous cycle.

DRG CD2AP expression assay. Using an additional set of animals which underwent the same procedures using the same protocols as those listed above, individual DRGs were processed in tandem for RNA and protein assays as follows:

qPCR. DRGs were extracted from exsanguinated rats perfused with $60 \mathrm{ml}$ $30 \%$ RNAlater (QIAGEN) in PBS. The spared DCn was then traced back to confirm the noninjured/sprouting DRG for dissection and storage in 100\% RNAlater. Individual DRGs were then homogenized and RNA extracted as per Hill et al. (2010) and the column flow-through preserved for protein analysis (see below). Amplicons for SYBR Green qPCR detection were designed as previously described (Harrison et al., 2014). RNA quality control, reverse transcription, and $\mathrm{qPCR}$ were performed according to Hill et al. (2010). Briefly, 250 ng of RNA input was used to generate cDNA using Quantitect RT mastermix (QIAGEN) that contains a mixture of oligo(dT) and random primers to reduce $3^{\prime}$ bias. PCRs were performed with $5 \mathrm{ng}$ input cDNA in triplicate using SYBR Green master mix (Roche) and a Corbett Rotorgene thermocycler (QIAGEN).

Protein assay. Protein was precipitated from column flow-through using 5 volumes of cold acetone overnight at $-20^{\circ} \mathrm{C}$. Precipitates were then centrifuged at $12,000 \times g$ for $10 \mathrm{~min}$, the supernatant removed and pellets air dried. Pellets were resuspended with $50 \mu \mathrm{l}$ chaotropic lysis buffer ( $7 \mathrm{~m}$ urea, $2 \mathrm{~m}$ thiourea, 1\% NP-40) for Western blot analysis.

Western blot analysis. Western blot procedures were performed as previously described (Harrison et al., 2008), with the following modifications: $10 \mu \mathrm{g}$ of DTT-reduced protein/lane was separated in $4 \%-12 \%$ gradient PAGE gels (Invitrogen). Protein was then transferred onto nitrocellulose membranes, before blocking for $1 \mathrm{~h}$ in antibody dilution buffer (ADB-PBS containing $0.05 \%$ Tween 20 and 5\% nonfat milk) before primary antibody incubation at $4^{\circ} \mathrm{C}$ for $18 \mathrm{~h}$ in $\mathrm{ADB}$ at the following concentrations: rabbit anti-CD2AP (1:20,000, gift from Andrey Shaw laboratory) (Grunkemeyer et al., 2005), mouse anti-GAPDH (Millipore) (1:2000), rabbit anti-TrkA (Millipore) (1:500), rabbit anti-p85 (1:1000), rabbit anti-phospho-ERK (1:1000), rabbit anti-phospo-AKT (1:1000), rabbit anti-total-ERK (1:1000), and rabbit anti-total-AKT (1:1000), all from Cell Signaling Technology. Membranes were then washed (PBST) before incubation with HRP-conjugated secondary antibodies (Jackson ImmunoResearch Laboratories) diluted 1:5000 in $\mathrm{ADB}$ at $20^{\circ} \mathrm{C}$ for $2 \mathrm{~h}$. Protein was detected with enhanced chemiluminescence and radiographic film according to standard protocols. Radiographs were scanned at 600 pdi for densitometric analysis using imageJ software. Band densities were normalized to housekeeping gene loading control (GAPDH). Experimental manipulations of PC12 cells, which produced samples for Western blot, were all performed on three separate occasions, with a single blot quantified from each yielding values of mean $\pm \mathrm{SD} ; n=3$.

Analysis of CD2AP expression during PNS and CNS development. Postnatal day $1,7,14,21$, and 35 rat pups ( $n=4$ each time) were anesthetized, decapitated, and their DRGs and brains removed before rapid freezing by plunging in liquid nitrogen. Whole frozen brains were homogenized in Trizol reagent (Invitrogen) as they thawed with a rotor-stator (Kinematica), and RNA extracted according to the manufacturer's protocol. Pooled DRGs were homogenized in RLT buffer with betamercaptoethanol using a glass-Teflon homogenizer and RNA extracted using a QIAGEN mini-kit and eluted with $50 \mu \mathrm{l}$ of $\mathrm{H}_{2} \mathrm{O}$. RNA quality control and qPCR was performed as above.

Analysis of CD2AP expression during PNS injury and regeneration. The nerve crush model was used to induce a robust injury and regeneration response in L4 and L5 DRG. To ensure that the maximum number of L4/L5 DRG neurons were injured and to prevent arbor expansion of any noninjured neurons in the same ganglia (i.e., to provide a "pure" population of injured neurons), the lumbar plexus was crushed just central to the branch of the posterior biceps and semitendinosus (PBST) nerves. In addition, the L4/L5 DCnn, which branch off of the spinal nerves very close to the DRG, were both crushed. Effectiveness of nerve crushes were evaluated by the following: (1) microscopic visual inspection of the crush sites, which were confirmed to be clear in appearance; (2) sensory testing of the limb after the animals awoke, confirming lack of responsiveness; and (3) observation of motor behavior after the animals awoke, confirming lack of movement of the affected joints. After the indicated survival time, animals were exsanguinated under pentobarbital anesthesia $(60 \mathrm{mg} / \mathrm{kg})$ by transcardial perfusion of PBS and RNA protected by perfusion of $60 \mathrm{ml} 30 \%$ RNAlater (QIAGEN). L4/L5 DRGs were removed and pooled for RNA extraction and qPCR as detailed above.

Whole-mount mouse skin immunofluorescent staining. Naive or collaterally reinnervated dorsal adult mouse skin was processed for wholemount immunofluorescent staining and clearing according to Li et al. (2011) with the modification that the stratum corneum was left intact (i.e., no removal by tape stripping). To visualize CD2AP-positive structures, skin samples were immersed in rabbit anti-CD2AP primary antibody (diluted 1:10,000; gift from Andrey Shaw laboratory), followed by rinse and then immersion in anti-rabbit Alexa-488 conjugate (diluted 1:500; Invitrogen). To colabel neural fibers, mouse monoclonal antibody against $\beta$-3-tubulin (TUBB3/Tuj1; Covance) was directly conjugated to Alexa-647 fluorophore according to the manufacturer's protocol (Invitrogen) and included (at 1:500 final concentration) in the anti-rabbit Alexa-488 incubation.

To prepare collaterally reinnervated skin for assessment of axons, mice were anesthetized (isoflurane preanesthesia followed by tri-bromo ethanol injection anesthetic), the skin incised, and the T10, T11, T12, T13, and L1 dorsal cutaneous nerves (DCNs) were cut and ligated to prevent their regrowth, and the skin closed with surgical staples. The innervated/ denervated border was determined acutely using the CTMR (Petruska et al., 2014) measured under light pentobarbital anesthesia (40-50 mg/kg) and clearly marked with permanent ink. Sensory arbor expansion then proceeded from the flanking DCNs (T9 and L2) into the denervated zone for 3 weeks. The migrated border of innervation was again determined before death using the CTMR and clearly marked with permanent ink, thus defining a region of skin that had been denervated but had regained innervation by axonal arbor expansion.

For imaging, an Olympus confocal microscope equipped with a $40 \times$ water objective was used to acquire $1024 \times 1024 x y$ slices at $1 \mu \mathrm{m}$ intervals through the $z$-plane. Images were then processed in Amira (FEI) software for background removal (median method) and deconvolution.

Neurite outgrowth assay: cerebellar granule neurons (CGNs) on inhibitory substrate. To elucidate transcripts with neurite arbor growthpromoting activity, genes with known intracellular signaling activity were selected from the microarray screen (Harrison et al., 2015). Expression plasmids encoding candidate genes were purchased from the public clone collection (Open Biosystems). Plasmids were electroporated into postnatal CGNs for neurite growth assay on inhibitory substrate (myelin-associated glycoprotein-expressing Chinese hamster ovary [MAG-CHO] cells) in 96-well format as previously described (Hutson et al., 2011). Briefly, CHO-MAG cells were seeded onto PLL-coated plates and left to adhere overnight. CGN neurons from postnatal day 7-9 Long-Evans rat pups were dissociated and dual transfected with gene of interest or mCherry control plasmid and GFP reporter plasmid (4:1 ratio gene of interest/reporter) by electroporation. Neurons were then seeded onto MAG-CHO plates and cultured for $48 \mathrm{~h}$ before fixing and staining with $\beta$-III tubulin antibody to reveal neurites. Mean neurite length per transfected neuron was calculated for all transfected neurons in a single well from four independent experiments.

PC12 culture, plasmid/siRNA lipofection and NGF-induced differentiation. PC12 cells were maintained in RPMI-1640 media supplemented with 10\% heat-inactivated horse serum and 5\% FBS in suspension.

For microscopy studies, cells were transfected after adhering overnight onto PDL-laminin-coated coverslips (neuVitro) in 24-well plates at a density of 10,000 cells $/ \mathrm{cm}^{2}$.

For protein analysis and immunoprecipitation studies, PC12s were transfected after adhering overnight onto PDL-laminin-coated $10 \mathrm{~cm}$ plates at a density of $50,000 \mathrm{cells} / \mathrm{cm}^{2}$. For protein overexpression, cells were transfected with $0.5 \mu \mathrm{g}$ of plasmid DNA and $2.5 \mu \mathrm{l}$ of Lipofectamine-2000 (Invitrogen) per milliliters of culture medium according to the manufacturer's instructions for $18 \mathrm{~h}$ in growth 
medium. For siRNA lipofection, $2 \mu \mathrm{l}$ of DharmaFECT-1 transfection reagent was used with $1.25 \mu \mathrm{l}$ of $20 \mu \mathrm{M}$ ON-TARGETplus SMARTpool CD2AP siRNA per milliliters of culture medium according to the manufacturer's instructions for $18 \mathrm{~h}$ in growth medium.

To differentiate PC12 cells, growth media were replaced with RPMI1640 media supplemented with $1 \%$ HIHS and $25 \mathrm{nM}$ mouse maxillary gland 2.5S NGF (Sigma) for $48 \mathrm{~h}$.

Coimmunoprecipitation assays. Following transfection with/without NGF stimulation as indicated, growth media were gently removed and plates were snap cooled on ice for $15 \mathrm{~s}$ before gentle washing with cold PBS and then scraped into $1.5 \mathrm{ml}$ centrifuge tubes with $1 \mathrm{ml}$ of cold PBS and the cells sedimented at $400 \times g$ for $4 \mathrm{~min}$ at $4^{\circ} \mathrm{C}$. Cells were then lysed using coimmunoprecipitation buffer ( $25 \mathrm{~mm}$ Tris, $\mathrm{pH} 8.5,150 \mathrm{~mm} \mathrm{NaCl}$, $1 \mathrm{~mm}$ EGTA, $1 \mathrm{~mm} \mathrm{NaF}, 1 \mathrm{~mm} \mathrm{NaVO}_{4}, 3 \mathrm{~mm}$ beta glycerol phosphate, $1 \%$ NP40, and 5\% glycerol, supplemented with complete protease inhibitor tablets, Roche) for $10 \mathrm{~min}$ at $4 \mathrm{C}$ with constant rotation. Lysate was then spun twice at $12,000 \times g$ for $10 \mathrm{~min}$ and the pellet discarded to ensure complete removal of insoluble debris. Protein concentration was then determined using the Bradford method according to the kit manufacturer's instructions (Bio-Rad).

A total of $25 \mu \mathrm{l}$ of washed protein A/G agarose bead sediment (Pierce) was used per IP and added to spin columns containing paper filters (Pierce); $200 \mu \mathrm{g}$ of $1 \mu \mathrm{g} / \mu \mathrm{l}$ protein lysate in coimmunoprecipitation buffer was added, mixed gently, and the required antibody added (CD2AP 1:5000, p85 1:50, TrkA 1:100) before incubation at 4C for $2 \mathrm{~h}$ with constant rotation. Following incubation, spin columns were spun at $200 \times g$ for $30 s$ and the unbound fraction removed and snap-frozen for analysis. Beads were washed 4 times with $400 \mu \mathrm{l}$ of coimmunoprecipitation buffer for $1 \mathrm{~min}$ at $4 \mathrm{C}$ with constant rotation. Columns were then spun at $200 \times g$ for $30 \mathrm{~s}$ and the flow-through discarded. Protein was then eluted by addition of $50 \mu \mathrm{l} \mathrm{Laemmli} \mathrm{sample} \mathrm{buffer} \mathrm{(5 \%} \mathrm{SDS,} 0.5 \mathrm{~m}$ DTT, $0.04 \%$ bromophenol blue, and $0.5 \mathrm{M}$ Tris- $\mathrm{HCl}, \mathrm{pH} 6.8$ ) and heating to $95^{\circ} \mathrm{C}$ for $5 \mathrm{~min}$ before spinning at $1000 \times g$ for $2 \mathrm{~min}$. Precipitates were analyzed by Western blot as above.

Neurite outgrowth assay-sholl analysis of PC12 cells. PC12 cells were transfected with CD2AP-GFP plasmids or GFP control plasmids and differentiated on PDL-laminin-coated coverslips as described above before gently washing 3 times for $10 \mathrm{~s}$ with $37^{\circ} \mathrm{C}$ prewarmed cytoskeleton buffer (CB: 60 mM PIPES, 27 mм HEPES, 10 mm EGTA, 4 mm $\mathrm{MgSO}_{4}, \mathrm{pH}$ 7.0) on a warming pad at $37^{\circ} \mathrm{C}$. Cultures were then fixed with $37^{\circ} \mathrm{C}$ prewarmed $\mathrm{CB}$ containing $4 \%$ PFA with $0.5 \%$ Triton for $10 \mathrm{~min}$ on a warming pad at $37^{\circ} \mathrm{C}$. Coverslips were then washed 3 times with room temperature PBS. Coverslips were immunostained using chicken anti-GFP (Invitrogen) diluted 1:2000 in immunostaining buffer (IB: $4 \%$ normal donkey serum, $0.4 \%$ Triton in PBS) for $1 \mathrm{~h}$ at room temperature, washed 4 times for $5 \mathrm{~min}$ with IB, stained with secondary anti-chicken Alexa-488 (Invitrogen) diluted 1:50 in $\mathrm{IB}$, washed 4 times for 5 min with IB, quickly dipped into $\mathrm{ddH}_{2} \mathrm{O}$ to remove salts/serum and mounted on slides using ProLong Gold media (Invitrogen) containing antifade reagent.

Whole coverslips were imaged using a $10 \times$ objective on a Nikon inverted microscope with motorized stage and mosaic field stitching. Images were then thresholded to clearly define transfected $\left(\mathrm{GFP}^{+}\right)$cells and their neurite profiles. Cells with neurites $2 \times$ the length of the cell body $(\sim 40 \mu \mathrm{m})$ were selected for Sholl analysis. This is a commonly used method to quantify axon morphology and outgrowth by quantifying the number of neurite crossings of each of the concentric radii set around the soma (Sholl, 1953). It also allows other quantifications, such as neurite arbor complexity and longest neurite. At least $100 \mathrm{PC} 12$ cells/condition were assessed from three independent experiments. Neurites of individual cells were traced using Neuron Studio software (version 0.9.92). Calculation of total neurite length per neuron and number of crossings per Sholl radius was then calculated using a custom MATLAB script.

PC12 cytoskeleton staining and filopodia counting. Cells were transfected, differentiated, and fixed using CB, 4\% PFA and stained using the immunostaining protocol as above. The following primary antibodies were diluted in IB: mouse monoclonal anti-TUBA ( $\alpha$-tubulin) clone DM1A (Millipore; diluted 1:250) and rabbit anti-CD2AP (Andrey Shaw laboratory; diluted 1:10,000) and labeled using anti-mouse Alexa-546 and anti-rabbit Alexa-488 secondary antibodies. Following secondary antibody incubation, filamentous actin (F-actin) was stained using biotin-conjugated phalloidin (Invitrogen) diluted 1:10 in PBS for $20 \mathrm{~min}$ at room temperature, washed 3 times for $1 \mathrm{~min}$ with PBS and then incubated with Pacific Blue-conjugated streptavidin (Invitrogen; diluted 1:25) in PBS for $20 \mathrm{~min}$ at room temperature, washed 3 times for $5 \mathrm{~min}$ with PBS before mounting as above.

High-resolution confocal stacks were taken of at least 10 random growth cones from 3 independent coverslips, with a $100 \times$ NA1. 3 objective using an Olympus confocal microscope at the Nyquist sampling limit. The microscope operator was blinded to experimental conditions by sample coding. To further reduce selection bias, image stacks of solitary cones were collected from fields in a line across the coverslip, viewed at $100 \times$. Image stacks were denoised using the medium local intensity method, and the background subtracted and the image deconvolved using Amira (FEI) software. Maximum intensity projections of each processed stack were then used for analysis using the following method: Using ImageJ software (Schneider et al., 2012), a $20 \mu \mathrm{m}$ line was traced centered at growth cone tips, $1 \mu \mathrm{m}$ from the extent of tubulin signals. Line histogram plots of F-actin signals were then used to count the number of filopodia per $\mu \mathrm{m}$ based on the line drawn outside the tubulinpositive border. Mean data per condition were analyzed using ANOVA followed by Fisher's LSD post hoc $t$ tests.

Endosome imaging and colocalization analysis. PC12 cells were transfected, differentiated, and fixed using 4\% PFA in cytoskeletal buffer (see above) without Triton and stained using the immunostaining protocol as above. The following primary antibodies were used: rabbit anti-CD2AP (Andrey Shaw laboratory; 1:10,000), goat anti-TrkA (R\&D Systems; 1:100), mouse anti-Rab7, mouse-anti RAB5, and mouse anti-pAKT 1:50 (all from Cell Signaling Technology). Appropriate secondary antibodies were used conjugated to either Alexa-488, Cy3, or Alexa-647 as indicated.

Growth cones were imaged as described above. $Z$-stacks were then denoised and deconvolved using Amira (FEI) software and colocalization quantified using the Colocalization Threshold plugin of Image that employs Costes' method (Costes et al., 2004) for unbiased analysis. Mean colocalization coefficients (Persons', M1 and M2) per condition were analyzed using ANOVA followed by Fisher's LSD post hoc $t$ tests.

\section{Results \\ CD2AP is identified as upregulated during axon growth of noninjured neurons}

Arbor expansion was assessed using the CTMR (Petruska et al., 2014) to define the border between innervated skin (T11 dermatome) and denervated skin (Diamond et al., 1992). Arbor expansion restored sensation to the entire denervated area by $28 \mathrm{~d}$ (Fig. 1E). Arbor expansion was first significantly detectable at $\sim 10 \mathrm{~d}$ when the sensory innervation border had expanded $\sim 1$ $\mathrm{mm}$ (repeated-measures ANOVA, $n=4$, post hoc HSD, $p=$ 0.009 ) (Fig. $1 E$ ). We therefore designated the $7 \mathrm{~d}$ time point (expansion not significantly increased, $p=0.143$ ) as reflective of an initiation phase. Reinnervation was essentially complete by CTMR testing by $28 \mathrm{~d}$. Therefore, the half-latency from surgery to full-reinnervation (14 d) was considered to reflect the maintenance phase of arbor expansion. To determine the profile of transcriptional response during arbor expansion, microarray expression profiles were generated from DRGs harvested from rats at either $7 \mathrm{~d}$ (initiation) or $14 \mathrm{~d}$ (maintenance) after surgery. As described in detail previously (Harrison et al., 2015), a threshold of a mean fold change of at least 1.2 with a $p$ value of $<0.05$ (determined by Limma) revealed 917 differentially expressed probe sets at day 7 versus naive and 1920 differentially expressed probe sets at day 14 versus naive.

For discovery of intracellular arbor expansion-regulating signaling molecules, the largest gene expression changes were considered regardless of what was already known about those genes. One of the expression differences of largest magnitude was CD2associated protein (CD2AP; mean fold change $=3.2, p=0.021)$. 

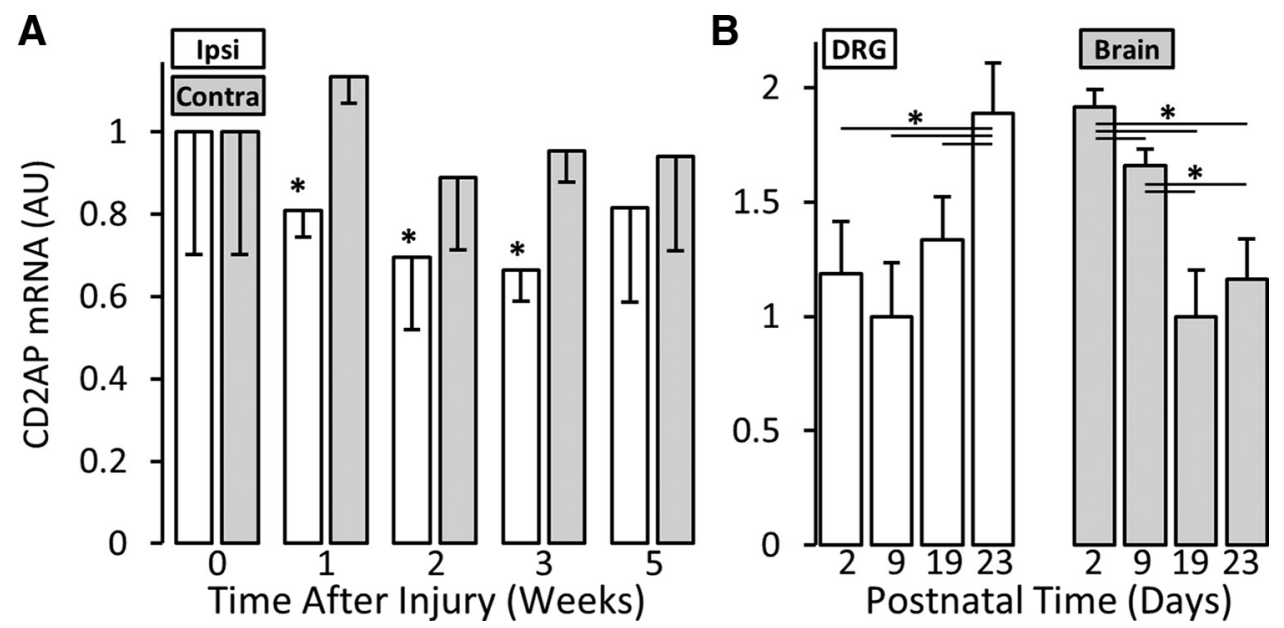

Figure 2. Regulation of CD2AP expression is growth-mode specific. $A$, Regulation of CD2AP mRNA levels after sciatic nerve crush. Samples are $L 4 / L 5$ whole DRG homogenates. Control values were set to 1. Contra, Contralateral; Ipsi, ipsilateral. *Statistically significant compared with contra (multivariate ANOVA, post hoc $t$ test). B, CD2AP mRNA expression during postnatal development. By convention, the lowest expression condition for each tissue sample was set to 1. Samples are whole tissue homogenates. * Statistically significant changes (ANOVA and post hoc $t$ test).

To confirm this, CD2AP mRNA expression levels were determined from independent experimental groups of T11 DRG (naive, $n=4 ; 7 \mathrm{~d}, n=8$; and $14 \mathrm{~d}, n=10)$ using qPCR. CD2AP mRNA increased significantly (ANOVA, post hoc $t$ test) during both the initiation ( $7 \mathrm{~d}$ : mean $\mathrm{FC}=1.664, p=0.012)$ and maintenance $(14 \mathrm{~d}$ : mean $\mathrm{FC}=1.549, p=0.006$, unequal variance assumed) phases (Fig. $1 F$ ). In accord with the mRNA regulation, $\mathrm{CD} 2 \mathrm{AP}$ protein was also upregulated after stimulation of arbor expansion (Fig. $1 F$ ).

Our long-term goal is to identify the molecular regulation specifically of axonal growth of noninjured adult neurons, and it is currently unclear the degree to which axonal collateral sprouting/arbor expansion shares intracellular regulatory/effector mechanisms with other axon plasticity processes. To determine whether CD2AP regulation is specific to arbor expansion or might be a general characteristic of many/all forms of axon growth, we also examined CD2AP expression levels in DRGs during axon regeneration after nerve injury and axon growth during embryonic development. As opposed to its increased expression in DRG housing noninjured neurons undergoing arbor expansion in the spared-dermatome model, CD2AP is significantly decreased in DRG housing injured neurons undergoing axonal regeneration (e.g., -1.4 mean fold change at time $7 \mathrm{~d}$, multivariate ANOVA with post hoc $t$ test, $p=0.012$ ) (Fig. $2 A$ ). Interestingly, CD2AP concentration is also regulated during the course of postnatal development in both DRG and whole brain (DRG: P2 vs $\mathrm{P} 23, p=0.018$; $\mathrm{P} 9$ vs $\mathrm{P} 23, p=0.002 ; \mathrm{P} 19$ vs $\mathrm{P} 23, p=0.015$ ) (brain: $\mathrm{P} 2$ vs $\mathrm{P} 9, p=0.003$; $\mathrm{P} 2$ vs $\mathrm{P} 19, p<0.001$; $\mathrm{P} 2$ vs $\mathrm{P} 23, p=$ 0.001; P9 vs P19, $p<0.001 ; \mathrm{P} 9$ vs P23, $p=0.004$ ) (Fig. $2 B$ ). These findings suggest that the profile of CD2AP expression may be plasticity context dependent.

\section{CD2AP protein is expressed in neurons}

$\mathrm{CD} 2 \mathrm{AP}$ is a cytosolic adaptor protein that serves as a docking scaffold for protein complexes engaged in growth factor signaling (Table 1). Prior studies have focused on CD2AP function at the immune synapse, in epithelia, in T-cell contacts, and in kidney function/disease (Table 1), whereas little is known about its function in neurons. However, CD2AP mRNA and protein have been observed in brain homogenates (Kirsch et al., 1999; Grunkemeyer et al., 2005) and are highly expressed in DRG neurons during development (Lehtonen et al., 2008) (Fig. 2B). Our Western blot assessments supported these previous observations, demonstrating the presence of CD2AP protein in adult naive rodent cerebellum, cerebral cortex, liver, and kidney (Fig. 3A), and demonstrated the utility of the antibody. The Allen Brain Atlas also indicates that CD2AP mRNA is present in adult rat brain in specific regions, notably regions with high constitutive plasticity, such as hippocampus, cortex, and cerebellum (Fig. $3 B, C$ ). Immunofluorescence assessment of tissue sections demonstrated CD2AP protein in cerebellar Purkinje cells (Fig. 3D-F) and in the DRG where it appeared to be concentrated predominantly (but not exclusively) in small and medium neurons, and some axons (Fig. 3G). CD2AP protein was also observed in naive adult hairy skin where, although it was observed predominantly in epidermal cells and blood vessel epithelia, it is also observed in axons projecting into the epidermis (Fig. 4). Thus, our protein expression studies show that CD2AP is expressed in many cell types, including in neurons.

\section{In vitro analyses reveal a role for $\mathrm{CD} 2 \mathrm{AP}$ in axon growth}

To determine the relative axon growth-regulating ability of $\mathrm{CD} 2 \mathrm{AP}$ versus other genes identified from our microarray analysis (Harrison et al., 2015), we used an established in vitro system with automated analysis of neurite outgrowth from postnatal CGNs seeded on an inhibitory substrate (Hutson et al., 2011). We overexpressed individual target genes as C-terminal GFP-fusion proteins. Overexpression of two plasmids, CD2AP-GFP and KLF7, significantly (ANOVA with post hoc $t$ test) increased average neurite length (Fig. 5A; CD2AP-GFP mean fold change = 1.43 vs GFP control, $p=0.023$; KLF7 mean fold change $=1.61 \mathrm{vs}$ empty vector control, $p=3.19 \times 10^{-7}$ ). From the microarray data presented in a separate manuscript (Harrison et al., 2015), KLF7 was determined to be significantly upregulated at $14 \mathrm{~d}$ (mean fold change $=1.411, p=0.0041$ ). That CD2AP performed similarly to KLF7 is especially encouraging because KLF7 is often used as a positive control for increasing neurite outgrowth and is regulated by NGF in DRG neurons (Lei et al., 2005; Blackmore et al., 2012). Conversely, shRNA-mediated reduction of CD2AP expression resulted in significantly decreased neurite length in accord with the degree of reduction of protein (Fig. 5B) (e.g., shRNA4 $=-1.50$ mean fold change vs scrambled sequence control, $p=0.0033$ ).

Recruitment of intracellular signaling complexes by the CD2AP scaffold is induced by action of multiple growth factors 

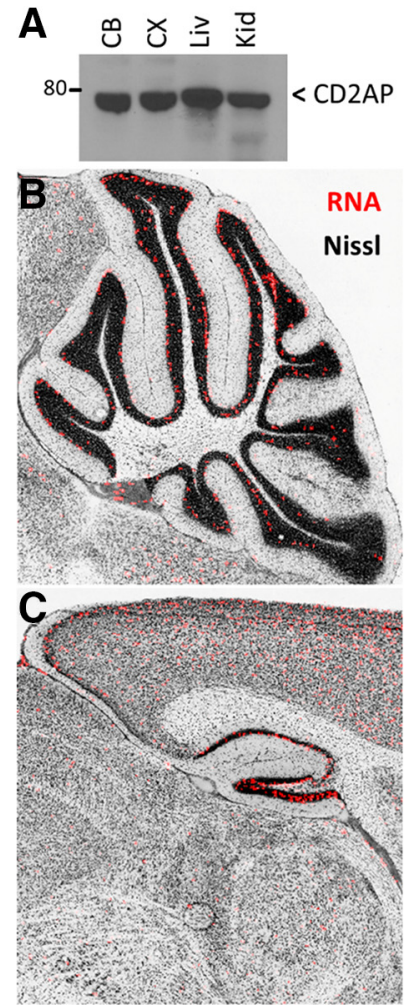

$\mathbf{D}$
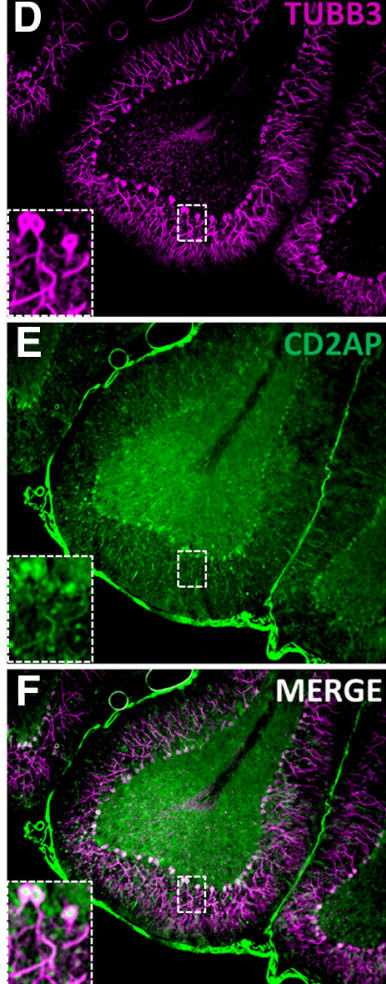

G

$\underline{20 \mu \mathrm{m}}$

Figure 3. CD2AP is expressed in neurons. A, Western blot assessment of CD2AP protein in tissue lysates. CB, Cerebellum; CX, cortex; Liv, liver; Kid, kidney. Allen Brain Atlas demonstrates CD2AP mRNA in cerebellum $(\boldsymbol{B})$ and hippocampus $(\boldsymbol{C}) . \boldsymbol{D}-\boldsymbol{F}, \mathbf{C D} 2 \mathrm{AP}$ protein expression in rat cerebellum. Note high expression levels in neurons. $\mathbf{G}, \mathrm{CD} 2 \mathrm{AP}$ protein in DRG. Note elevated levels of punctate staining in small diameter soma (closed arrowheads) and axons (open arrowheads).
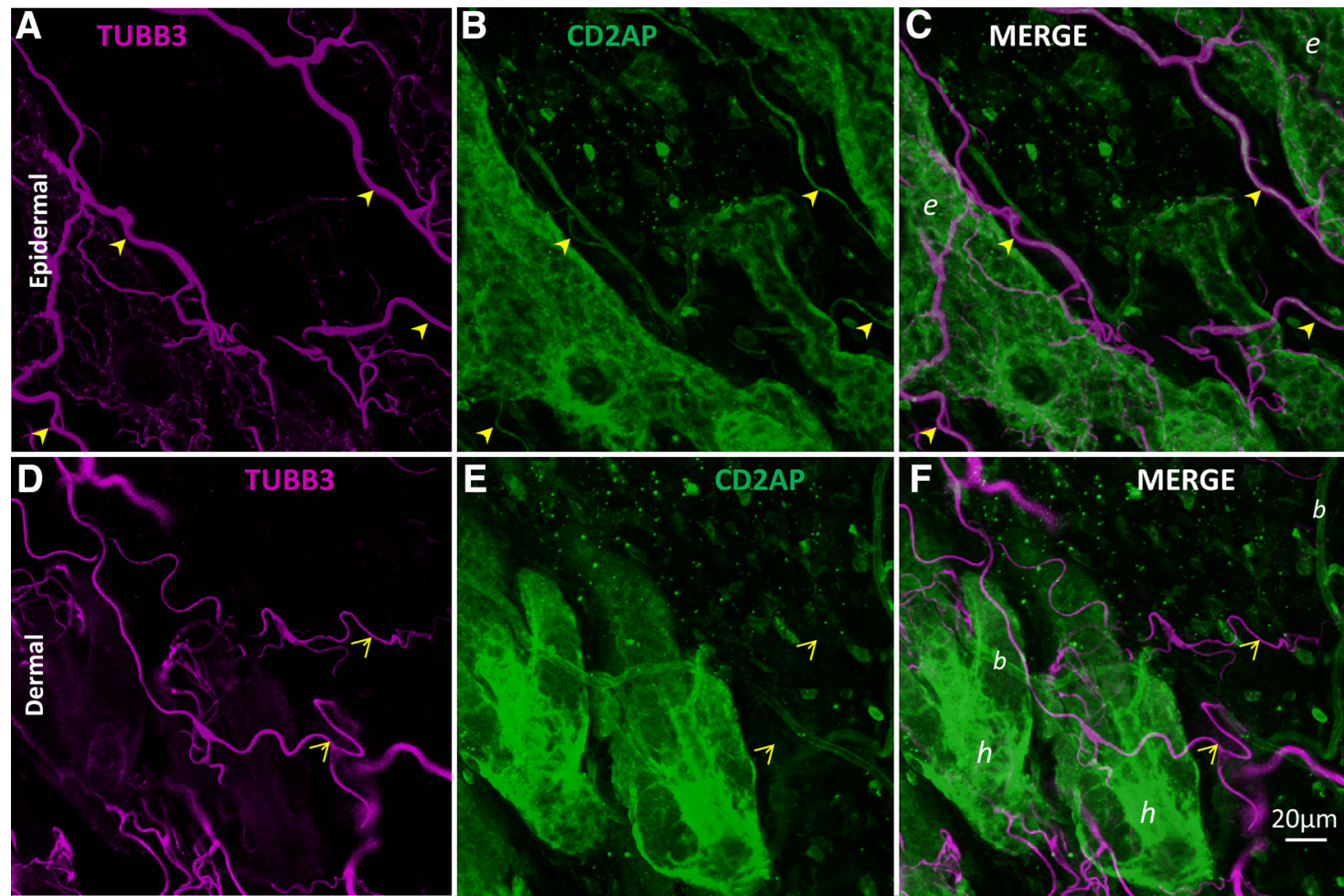

Figure 4. CD2AP is expressed in axons in superficial skin. Whole naive adult mouse dorsal skin was immunostained for CD2AP (green) and neuron-specific tubulin (TUBB3, magenta). Skin was cleared using organic solvent to allow confocal imaging throughout the tissue in whole mount. $\boldsymbol{A}-\boldsymbol{C}$, Maximum-intensity projection of confocal slices acquired from $10 \mu \mathrm{m}$ through $30 \mu \mathrm{m}$ into the tissue from the epidermal surface. A subpopulation of epidermal axons are CD2AP-positive (filled arrowheads). $\boldsymbol{D}-\boldsymbol{F}$, Maximum-intensity projection of slices from $40 \mu \mathrm{m}$ through $80 \mu \mathrm{m}$ from the epidermal surface (therefore dermis). CD2AP is largely undetectable in axons in the dermis (open arrowheads). In merged images: $b$, Blood vessel; $e$, epidermis; $h$, hair follicle. 


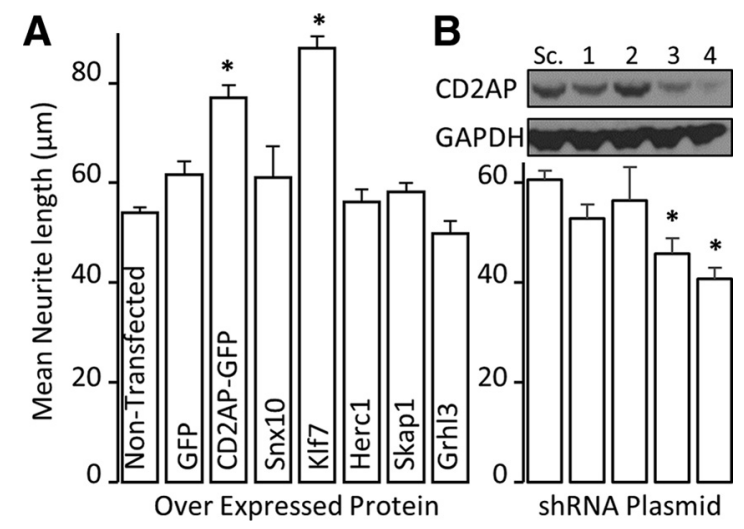

Figure 5. Automated screening using cultured postnatal rat cerebellar granule neurons reveals that CD2AP is a positive regulator of axon outgrowth. $\boldsymbol{A}$, Electroporation of expression plasmids for the indicated genes into CGNs reveals effects on axon outgrowth. *Statistically significant changes compared with GFP (ANOVA and post hoc $t$ test). $\boldsymbol{B}$, Reduction of CD2AP protein levels using four different shRNA plasmids (1-4) with differing efficiencies reduced outgrowth in accordance with CD2AP levels. Inset (over neurite-length bar graph), Example Western blot of CD2AP protein expression after transfection of PC12 cells with siRNA plasmids (1-4) or scrambled-sequence control (SC.) plasmid. * Statistically significant changes compared with scrambled-sequence plasmid (ANOVA followed by post hoc $t$ test).

on different cell types, including EGF and VEGF acting on kidney podocytes and by GDNF acting on cultured sympathetic neurons (Table 1). Ideally, the involvement of CD2AP in arbor expansionrelated processes would include assessment in the whole animal where the multitude of neuron-cell interactions is orchestrated. However, germline deletion of CD2AP expression causes critical kidney abnormalities and mice die at an early age (Kim et al., 2003), and conditional and/or inducible knock-out animals are not currently available. Also, we observed that CD2AP expression is decreased by direct axonal injury (Fig. $2 A$ ) and also by tissue disruption during culturing of adult neurons (data not shown), precluding the use of adult neuron in vitro preparations. CD2AP was robustly expressed in cultured PC12 cells, and its expression was significantly upregulated (mean fold change $=1.90, n=5, t$ test, $p=0.008$ ) by NGF treatment (Fig. 6A), a trophic factor known to induce PC12 cells to extend neurites (Greene and Tischler, 1976). Similarly, sensory arbor expansion in vivo is mediated at least partially through NGF signaling (Diamond et al., 1992). We therefore opted to use PC12 cells for mechanistic studies. In agreement with studies performed in CGNs, overexpression of CD2AP significantly increased mean neurite length ( mean fold change $=1.32$ ) and complexity in PC12 cells as assessed by Sholl analysis (Fig. 6B-E). These functional studies conducted in vitro supported a role for CD2AP in axon elongation and collateral sprouting.

\section{CD2AP positively regulates the number of filopodia on $\mathrm{PC} 12$} growth cones

In a variety of cell types, CD2AP locates to structures near the cell membrane where it couples growth factor signaling with the local actin cytoskeleton (Table 1). We therefore sought to determine whether CD2AP plays a similar role in neurons. To determine the subcellular distribution of CD2AP in NGF-stimulated PC12 cells, PC12 cells were triple-stained with phalloidin (which binds to F-actin), and with antisera against CD2AP and tubulin. CD2AP immunostaining was punctate in the soma and neurites, and accumulated at F-actin ${ }^{+} /$tubulin $^{-}$neurite tips, branch points, and swellings (Fig. 7). These observations are similar to those in other cells where CD2AP concentrates into punctae in the cytosol
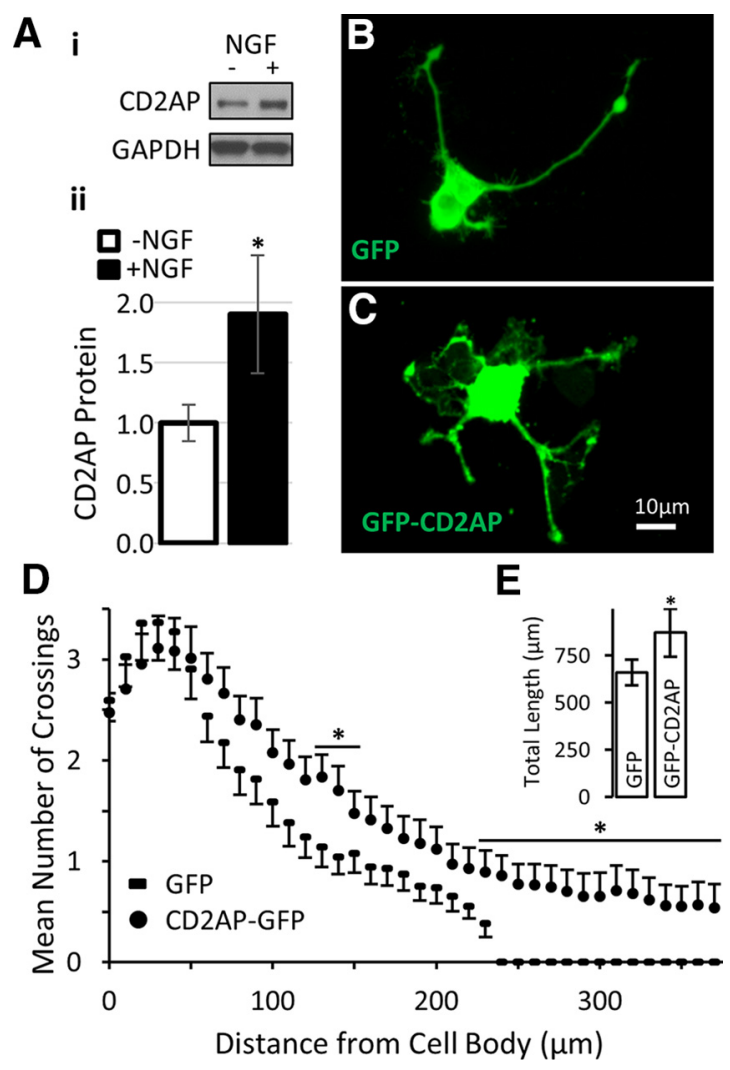

Figure 6. NGF treatment upregulates $C D 2 A P$, which is a positive regulator of $P C 12$ neurite growth and complexity. $\boldsymbol{A}, \mathrm{PC} 12$ cells were treated with NGF for $24 \mathrm{~h}$ before harvesting and processing for Western blot analysis. Ai, Representative blot. Aii, Densitometric quantification. *Significant difference (Student's $t$ test). The effect of increasing the levels of CD2AP on neurite morphology was examined with PC12 cells transfected with plasmids for GFP (control) or GFPCD2AP fusion protein for $24 \mathrm{~h}$ and then treated with NGF for $48 \mathrm{~h}$. Examples of neurite morphology are provided for GFP-transfected (B) and GFP-CD2AP-transfected (C) PC12 cells. Neurite morphology of transfected populations was characterized by Sholl analysis $(\boldsymbol{D})$ and by total neurite length per cell $(\boldsymbol{E})$. * Statistically significant difference between groups (repeatedmeasures ANOVA with post hoc $t$ test).

(Cormont et al., 2003) where it regulates actin dynamics during membrane ruffle and lamellipodia formation (Zhao et al., 2013). In PC12 cell homogenates, we determined that endogenous CD2AP protein levels were increased by NGF treatment (Fig. 6A) and that this increase continued and was maintained for at least $72 \mathrm{~h}$ with continued NGF treatment (data not shown). We therefore examined the effects of CD2AP concentration on the actin structures in growth cones. PC12 growth cones have multiple filopodia composed of F-actin. Overexpression of a GFP-CD2AP fusion protein caused an $\sim 33 \%$ increase in the number of filopodia (Fisher's LSD: $p=0.0012$ ), whereas downregulation of CD2AP with siRNA caused a $\sim 50 \%$ decrease $(p=0.011)$ (Fig. 8). Thus, CD2AP is localized at key F-actin structures in neurites and growth cones, CD2AP protein levels are positively regulated by $\mathrm{NGF}$, and in turn positively regulate filopodia formation in PC12 cells.

CD2AP forms a novel multiprotein complex with TrkA and p85, and is a positive regulator of AKT phosphorylation Having established a link between CD2AP concentration and the structure of the actin cytoskeleton in growth cones, we next sought to characterize the involved signaling pathways. NGF is necessary for axonal arbor expansion of at least some neurons in the spared dermatome model of collateral sprouting (Diamond 

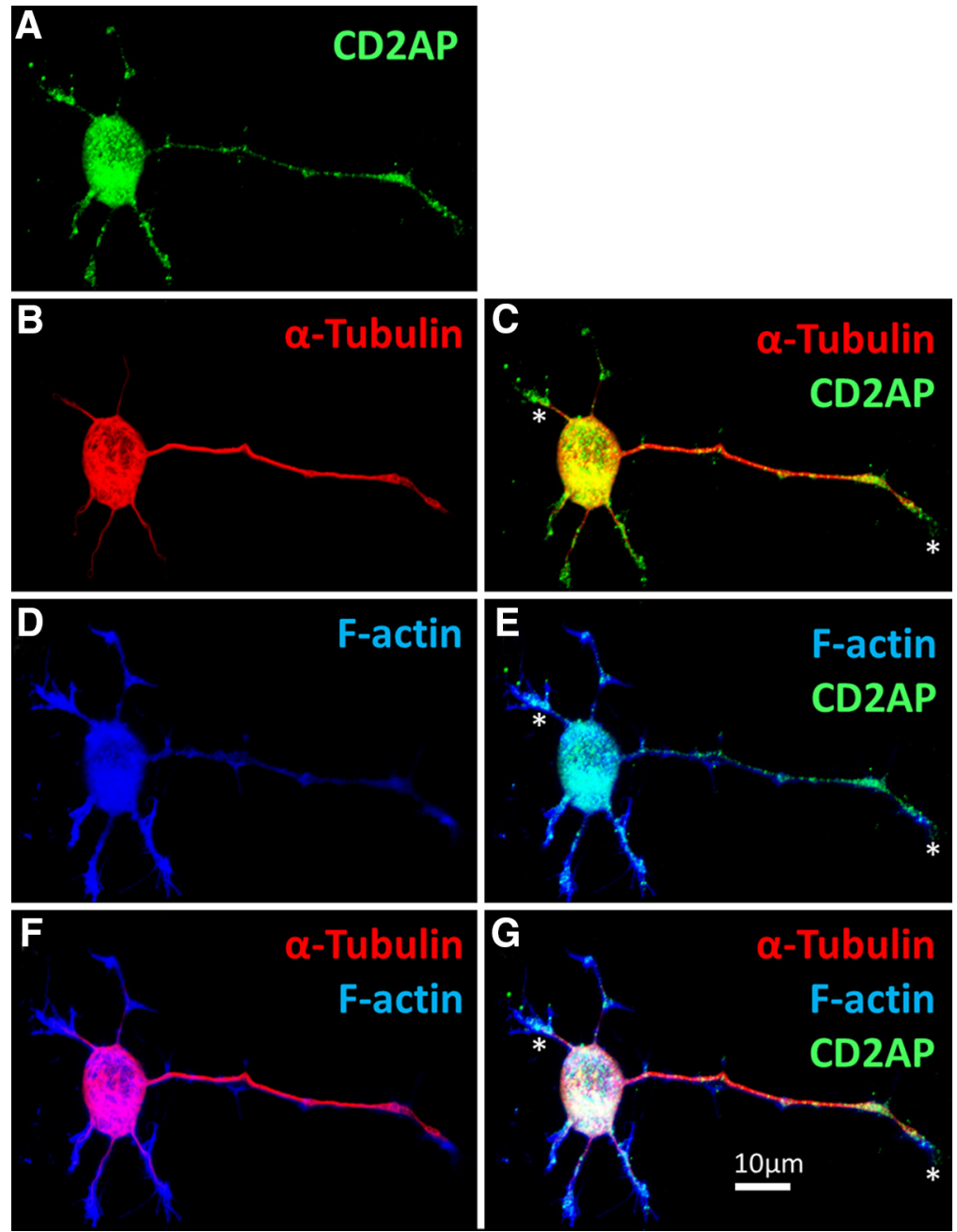

Figure 7. CD2AP locates to the growing tips of PC12 neurites. PC12 cells were treated with NGF for $48 \mathrm{~h}$, fixed, and costained to visualize the following: $\boldsymbol{A}, \mathrm{CD} 2 \mathrm{AP}$ (green); $\boldsymbol{B}, \boldsymbol{C}, \alpha$-tubulin (red); and $\boldsymbol{D}, \boldsymbol{E}$, F-actin (using phalloidin; blue). CD2AP locates to tubulin $^{-} /$F-actin ${ }^{+}$neurite tips $(\boldsymbol{F}, \mathbf{G}) .{ }^{*}{ }^{*}$ D2AP-positive neurite tip (growth cone).

et al., 1992). Growth factor signaling relies on multiple effector cascades to transduce context information and generate the appropriate responses (Petruska and Mendell, 2004). Previous studies in non-neuronal cells/tissues determined that CD2AP serves as a docking station, recruiting signaling effectors to initiate cascades from multiple extracellular factors (Table 1), but no such role for CD2AP in NGF signaling had been previously described. To determine whether CD2AP does play a role in NGF signaling, we examined protein constituents of immunoprecipitated CD2AP complexes and the effects of CD2AP concentration on phosphorylation (i.e., activation) of known NGF pathway effectors upon stimulation of PC12 cells with NGF.

To observe CD2AP and TrkA association in growth cones, we examined deconvolved high-resolution confocal $z$-stack images to quantify colocalization. The degree of colocalization was quantified using Costes' method for unbiased threshold and significance calculation in 3D volumes (Costes et al., 2004). Approximately $55 \%$ of fluorescent signal from either protein colocalized with above-threshold levels of the other protein (Fig. 9A-E), implying that the majority (but not entirety) of the CD2AP pool is associated with TrkA.

To determine whether the spatial association based on microscopy was also reflected in protein-protein binding, CD2APcontaining complexes were precipitated from homogenized
PC12 cells and the levels of TrkA were measured. In homogenates from $\mathrm{PC} 12$ cells not treated with NGF, CD2AP coprecipitated with low but detectable levels of TrkA. TrkA was detected in CD2AP precipitates from homogenized PC12 cells, which had been treated with NGF for $5 \mathrm{~min}$ or $24 \mathrm{~h}$ (Fig. $9 F$ ). Together, these data demonstrate a novel interaction of CD2AP with TrkA that is rapidly induced by NGF treatment and remains for at least $24 \mathrm{~h}$ of continued exposure to NGF.

Having established that a novel interaction occurs between CD2AP and TrkA during NGF-induced signaling, we next sought to determine whether CD2AP might play a role in specifying downstream signaling. CD2AP has been shown to acutely regulate (for up to $30 \mathrm{~min}$ ) two signaling cascades downstream of growth factor receptors: the PI3K/AKT and MAPK/ERK pathways (Table 1). Interestingly, similar to the temporally biphasic responses known for NGF-induced effects (Petruska and Mendell, 2004), these intracellular signaling cascades are known to be either transient or sustained, with the sustained response phase displaying different characteristics than the transient response. In cases where a sustained response is induced, there is often a physical translocation of signaling components to the soma and often to the nucleus to drive transcriptional responses, including those affecting neurite outgrowth (Marshall, 1995; Limpert et al., 2007). However, a role for CD2AP in chronic signaling, particularly long-distance retrograde signaling, has to our knowledge not been established. Because this form of long-distance sustained signaling could be expected in our model of axonal arbor expansion, we sought to determine whether CD2AP levels could regulate phosphorylation (activation) of PI3K/AKT and MAPK/ERK pathways and localization of signaling complex components following $24 \mathrm{~h}$ of NGF stimulation. Reduction of CD2AP protein concentration by siRNA treatment significantly reduced the levels of NGF-induced phospho-AKT by a mean of 2.85-fold ( $p=0.049$ ), whereas ERK phosphorylation was not significantly affected (Fig. 10 A, B), suggesting that CD2AP coordinates responses specifically through this signaling cascade/mode in NGF-stimulated PC12 cells.

Having observed that CD2AP regulated signaling via AKT but not via MAPK in NGF-stimulated PC12 cells, we sought to identify possible mechanisms by which NGF signaling might lead to CD2AP-regulated activation of AKT. A principal activator of AKT is PI3K (through 3-phosphoinositide-dependent protein kinase 1). The p 85 regulatory subunit of PI3K binds directly to the cytosolic domain of growth factor receptors via phophotyrosine-SH2domain interactions (Domchek et al., 1992), resulting in PI3K activation. PI3K then phosphorylates 3-phosphoinositide-dependent protein kinase 1, which in turn phosphorylates and activates AKT. Also, p85 directly interacts with the N-terminal SH3-domaincontaining region of CD2AP (Huber et al., 2003). We therefore hy- 

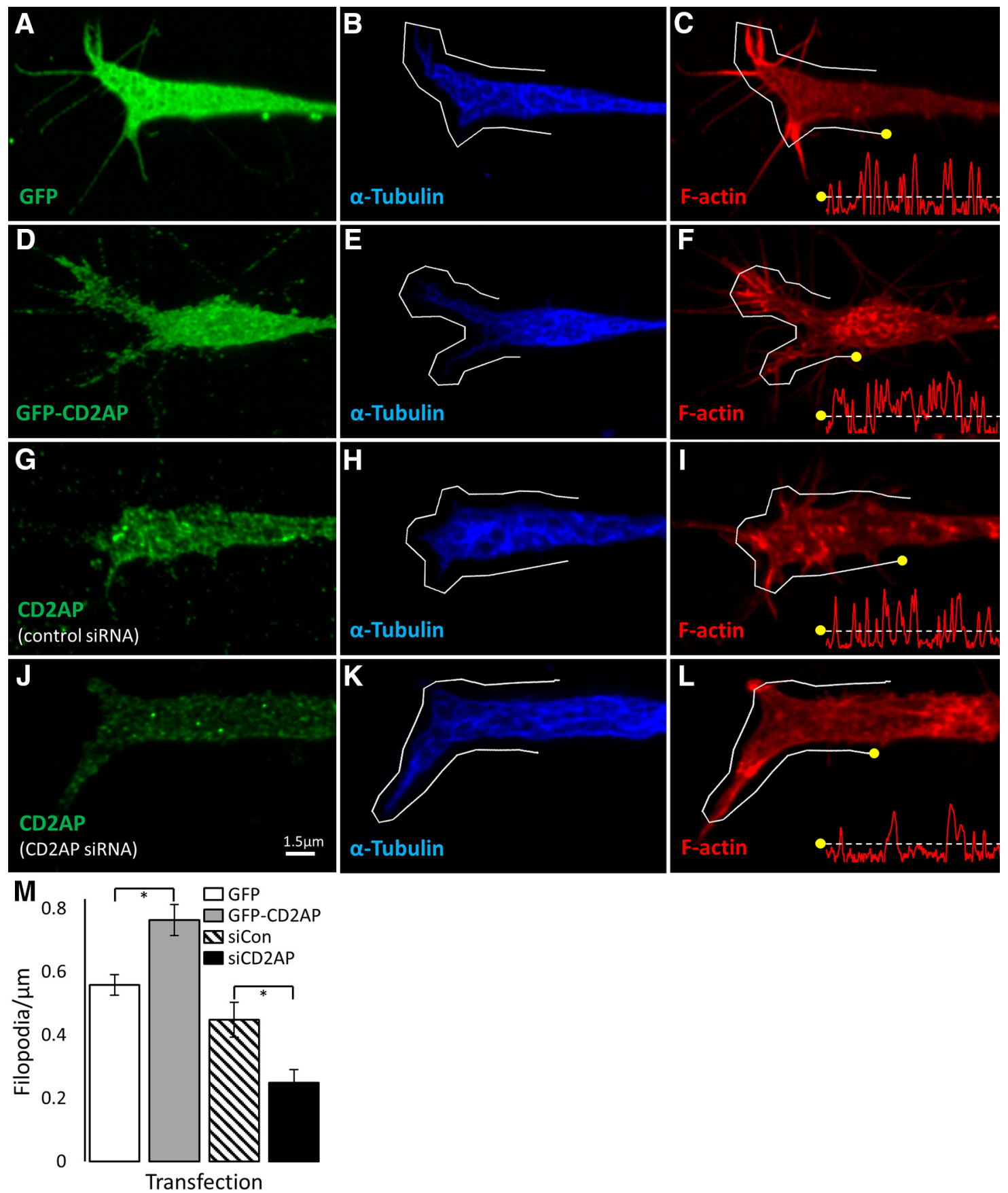

Figure 8. CD2AP is a positive regulator of the number of filopodia on growth cones. $P(12$ cells were transfected with GFP $(\boldsymbol{A}-\boldsymbol{C})$, GFP-CD2AP fusion protein (D-F), control siRNA (G-I), or CD2AP siRNA $(J-L)$ for $24 \mathrm{~h}$ before NGF treatment for $48 \mathrm{~h}$. Cells were fixed and stained to visualize F-actin (using phalloidin; red; $(\boldsymbol{F}, \boldsymbol{I}, \boldsymbol{L}), \alpha$-tubulin (blue; $\boldsymbol{B}, \boldsymbol{E}, \boldsymbol{H}, \boldsymbol{K}$ ), and either GFP (green; $\boldsymbol{A}, \boldsymbol{D})$ or $(D 2 A P$ $($ green; $G, J)$. Growth cones were imaged by confocal microscopy using $100 \times$ objective with $5 \times$ digital zoom. Images are representative deconvolved maximum-intensity projections. Line histograms were generated for lines exactly $20 \mu \mathrm{m}$ in length applied exactly $1 \mu \mathrm{m}$ outside of the tubulin-positive boundary (gray lines). Registration marks (yellow dots) indicate how the histogram relates to the line $(x$ axes $=$ distance, $y$ axes $=\log$ of actin fluorescence intensity). $\boldsymbol{M}$, Mean number of filopodia per condition. * Significant difference ( $t$ test). Error bars indicate SEM.

pothesized that, following NGF stimulation, CD2AP positively regulates the AKT pathway by interacting with $\mathrm{p} 85$ and recruiting p85 to TrkA in a multiprotein complex. We tested this by altering the levels of CD2AP in NGF-stimulated PC12 cells and measuring the levels of p85 and TrkA in immunoprecipitated protein complexes. In accord with our hypothesis, siRNA-mediated reduction of $\mathrm{CD} 2 \mathrm{AP}$ concentration resulted in a qualitative reduction in levels of p85 in TrkA-containing protein complexes (Fig. 10C). As an indication of the specificity of the interaction, the same effect was observed when assessing the level of TrkA in p85-containing complexes. As a further measure of this interaction, we quantified the spatial colocalization of p85 and TrkA in PC12 cell neurites. Confocal microscopy revealed that siRNA-mediated reduction of CD2AP concentration resulted in a significant reduction in colocalization of $\mathrm{p} 85$ and TrkA in growth cones by mean $18 \%(p=0.034)$ (Fig. 10D-P). In addition, overexpression of CD2AP via transfection with a plasmid for GFP-CD2AP fusion protein resulted in a significantly $(p=$ 0.031 ) increased colocalization of p 85 and TrkA by mean $45 \%$. These data suggest that CD2AP scaffold protein supports the recruitment of $\mathrm{p} 85$ to the TrkA receptor in neurites upon NGF 

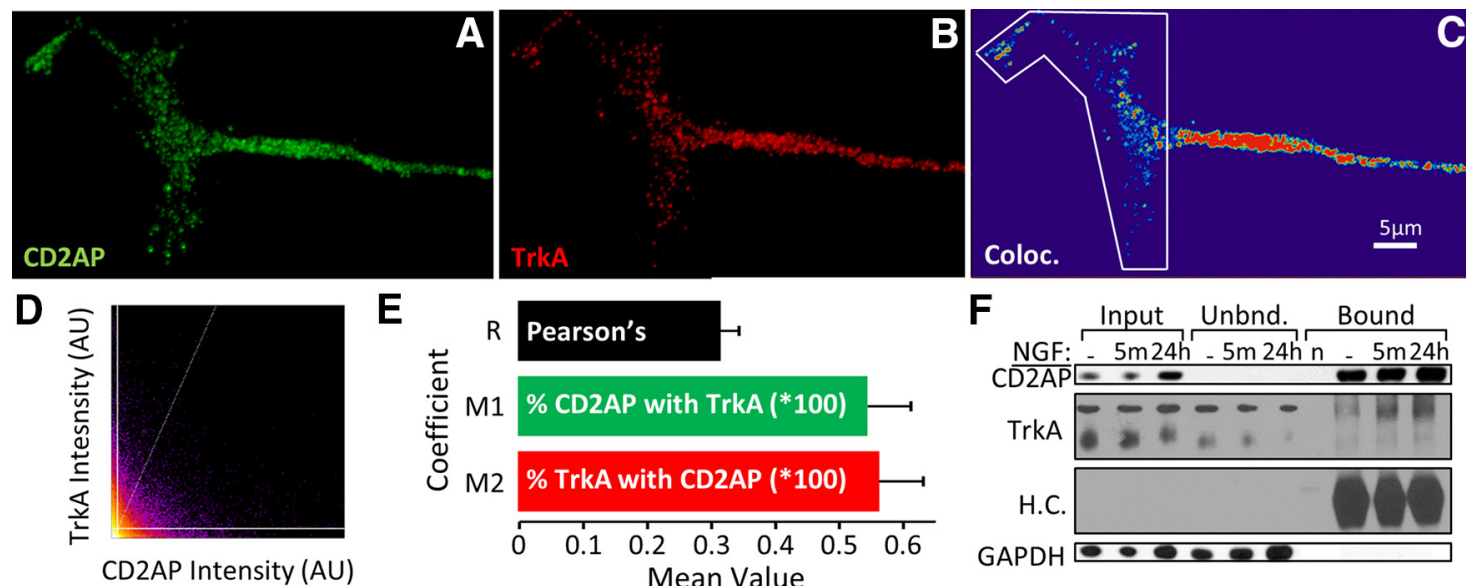

$\mathbf{F}$

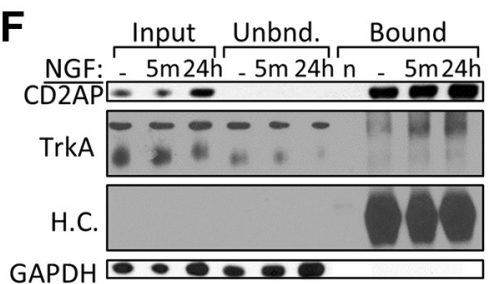

Figure 9. CD2AP forms complexes with the NGF receptor TrkA. Representative maximum-intensity projection of a representative PC12 growth cone stained to visualize CD2AP (green; $A$ ) and TrkA $(\operatorname{red} ; \boldsymbol{B})$ with associated colocalization heat map $(\boldsymbol{C})$ and intensity scatter plot from the outlined area (D). $\boldsymbol{E}$, Mean Pearson's correlation $(R)$ and Mander's coefficients $(M 1=$ percentage of $C D 2 A P$ signal associated with TrkA; M2 = percentage of TrkA signal associated with (D2AP) in PC12 growth cones. $\boldsymbol{F}$, Protein samples from NGF-treated PC12 cells were immunoprecipitated with anti-CD2AP and assessed by Western blot for CD2AP, TrkA, IG heavy chain (H.C.; this serves as a loading control for the bound fraction and shows that there is no antibody remaining in the unbound fraction), and GAPDH. $n=$ antibody control lane.

stimulation of PC12 cells, supporting the hypothesis that $\mathrm{CD} 2 \mathrm{AP}$ is a positive regulator of the AKT pathway during neurite structural plasticity.

\section{CD2AP is associated with RAB5-bound endosomes and positively regulates TrkA location to endosomes}

Addressing mechanisms of long-range signaling is especially pertinent to sensory neurons whose fibers can reach meters in length in large animals. Biochemical signaling over long distances requires the signaling complex to be highly compartmentalized, beginning at cell membrane lipid rafts, before being packaged into concentrated foci for transport, usually in signaling endosomes (SEs). CD2AP has been observed associated with endosomes in non-neural cells (Table 1), and our microscopy data indicate a subcellular distribution of CD2AP in DRG neurons and axons (Fig. 3G) and in PC12 cells (Fig. 7) that could reasonably include endosomes. We therefore sought to determine whether CD2AP was associated with SEs present in growth cones. Consistent with observations in other cell types (Table 1), CD2AP colocalizes with early endosomes, here labeled with $\mathrm{RAB} 5$, in PC12 cell growth cones (representative growth cone shown in Fig. 11A-C). Long-range NGF signaling in sensory neurons is regulated, at least in part, by retrograde transport of NGF bound to TrkA in RAB5-decorated endosomes (Deinhardt et al., 2006). Given our observation of CD2AP colocalization with RAB5, we also sought to determine whether CD2AP levels might affect TrkA compartmentalization in endosomes. Following transfection of NGF-stimulated PC12 cells with CD2AP siRNA, TrkA:RAB5 colocalization was significantly $(p=0.021)$ reduced by mean $21 \%$ (Fig. $11 D-H$ ). Following transfection of NGFstimulated PC12 cells with GFP-CD2AP, TrkA:RAB5 colocalization was increased $(p=0.043)$ by mean $20 \%$ (Fig. $11 D-H)$. Together, these data suggest that CD2AP is a positive regulator of TrkA endocytosis and translocation into endosomes.

Considered together, our observations suggest that CD2AP acts as a positive regulator of NGF signaling through endocytosis of TrkA and subsequent activation of the AKT pathway. It was reasonable to consider that, during axonal arbor expansion into denervated skin, CD2AP protein may be involved in NGF signaling in axons innervating the target tissue. We therefore examined skin that had been denervated and reinnervated by collateral sprouting of noninjured axons, stained for CD2AP and neuronspecific tubulin (TUBB3). In support of this consideration, $\mathrm{CD} 2 \mathrm{AP}$ was present in axons that had reinnervated formerly denervated skin (Fig. 12).

\section{Discussion}

Despite its fundamental importance for adult nervous system homeostasis, response to injury, and disease etiology, the molecular control of axonal structural plasticity in adult noninjured neurons is largely unknown. Screening revealed candidate genes, including some known to play a role in regulating intracellular signaling. These are of particular interest because NGF is the only known signaling factor clearly regulating collateral sprouting in the spared dermatome model (e.g., Diamond et al., 1992; but see Maysinger et al., 2008), but NGF has roles in stimulating numerous forms of plasticity (Petruska and Mendell, 2004). Understanding the principles at work in the various forms of NGFinduced plasticity and realizing the therapeutic potential of manipulating these forms of plasticity requires a dissection of which specific pathways are involved with each. Because there are many downstream effects of NGF signaling, it is likely that there are factors that specify which subsets of the numerous pathways are activated. For example, NGF rapidly induces sensitization of sensory neurons (e.g., Cheng and Ji, 2008), but sensitization may not occur during NGF-dependent collateral sprouting (Pertens et al., 1999).

Our transcriptomic screen (Harrison et al., 2015) revealed $\mathrm{CD} 2 \mathrm{AP}$ as highly regulated during collateral sprouting. CD2AP associates with multiple growth factor receptors and directs downstream signaling (Table 1). Here we demonstrate a novel interaction with the NGF receptor, TrkA.

Given the clear transcriptional response induced in the DRG during arbor expansion in the spared dermatome model (Harrison et al., 2015), which is dependent at least in part on NGF, it is reasonable to consider a role for long-distance retrograde signaling mechanisms involving NGF:TrkA:CD2AP. CD2AP links receptor signaling components with the endocytosis machinery in non-neuronal cells (Lynch et al., 2003). We observed that CD2AP colocalizes with the early endosomes in PC12 cells and that increasing levels of CD2AP concomitantly increases the concentration of TrkA associated with these endosomes. Upon NGF:TrkA 
A

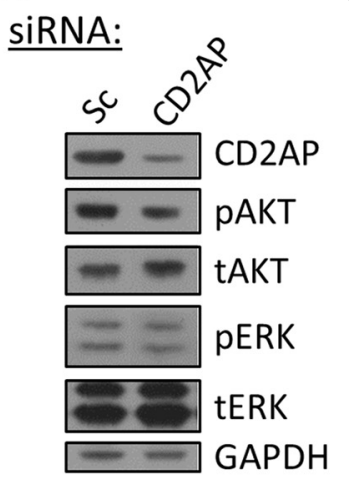

B

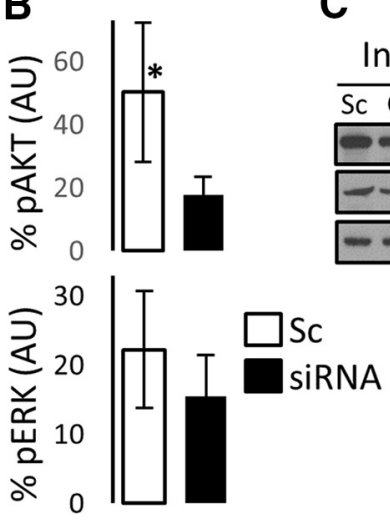

C

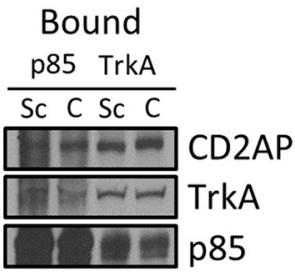

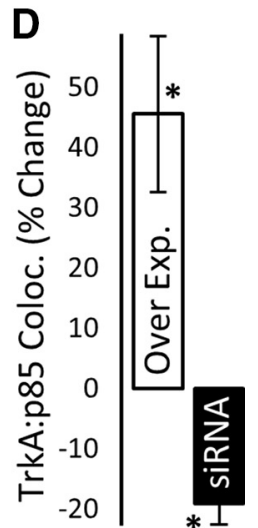
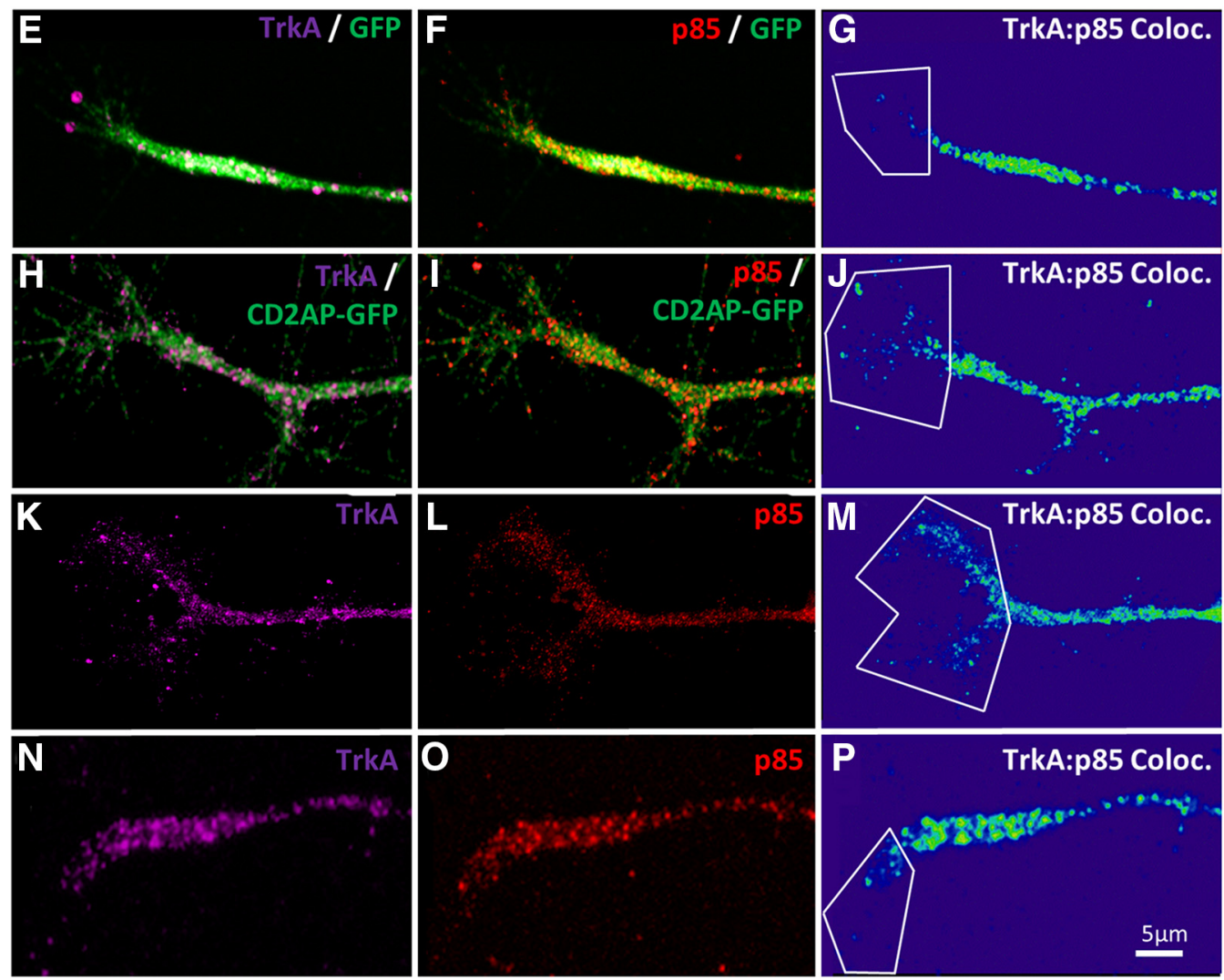

Figure 10. CD2AP is a positive regulator of AKT phosphorylation and increases p85 recruitment to TrkA complexes. $A$, Western blot assay of protein samples from NGF-treated PC12 cells assessed for phospho-AKT (pAKT), total-AKT (tAKT), phospho-ERK (pERK), total-ERK (tERK), and loading control (GAPDH) following transfection with scramble control (SC) or CD2AP siRNA. B, Densitometric quantification of pAKT and pERK, relative to tAKT and tERK, respectively. C, Western blot assay of p85 and TrkA immunoprecipitates following transfection with scramble control (SC) or CD2AP ( $C$ ) siRNA. CD2AP, TrkA, and p85 protein concentrations are shown in input (In) and bound fractions. D, Quantification of TrkA:p85 colocalization in growth cones following transfection with GFP (E-G), GFP-CD2AP $(\boldsymbol{H}-\boldsymbol{J})$, scramble control $(\boldsymbol{K}-\boldsymbol{M})$, or CD2AP siRNA $(\boldsymbol{N}-\boldsymbol{P}) . \boldsymbol{G}, \boldsymbol{J}, \boldsymbol{M}, \boldsymbol{P}$, Representative images from the 3D colocalization analyses are shown for each condition. *Statistically significant changes compared with the respective control (ANOVA, followed by $t$ test compared with control).

binding and endocytosis, TrkA-positive endosomes have multiple fates. They may be recycled to the lysosome for degradation or sent back to the membrane for continued local signaling. In the latter, receptor complex turnover by endocytosis can result in local elevations of signaling cascades within growth-structures, thereby enhancing outgrowth (e.g., Georgieva et al., 2011).

Additionally, endosomes can function as mobile rafts from which signaling continues (SEs) during long-range retrograde transport to the soma, and potentially into the nucleus (for review, see Matusica and Coulson, 2014). Our initial qualitative observations of CD2AP puncta in cell bodies and processes suggested that CD2AP may be associated with endosomes in neu- rons, perhaps even SEs. In PC12 cells and in neurons, a pool of TrkA-containing SEs destined for long-range signaling are initially RAB5-decorated and sorted to RAB7-positive late endosomes for retrograde transport (Matusica and Coulson, 2014). CD2AP may act to influence this sorting through its interactions with RAB GTP-ases (e.g., Rab4) (Cormont et al., 2003), a large family of multifunctional proteins involved in cytoskeletonassociated membrane plasticity (Stenmark, 2009). We demonstrate a novel association between CD2AP and early endosomes as defined by RAB5. Previous studies report no colocalization of CD2AP with RAB5 in non-neuronal cells (Welsch et al., 2005), suggesting a neuron-specific (or PC12 cell-specific) role for CD2AP 

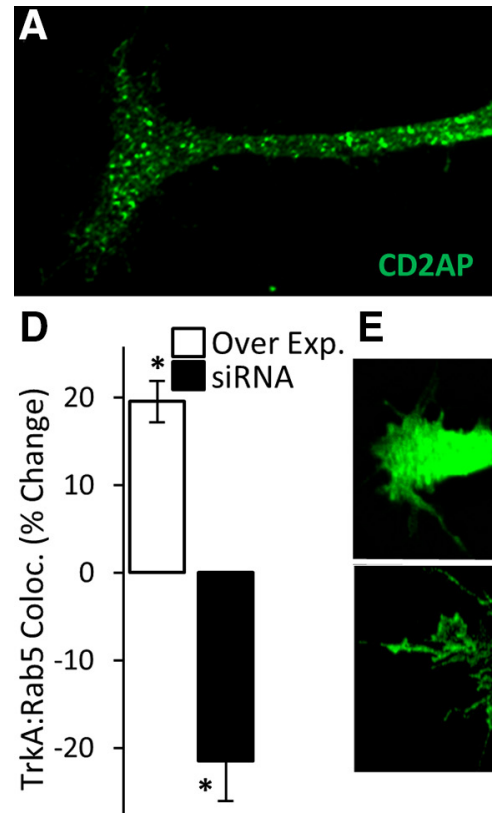

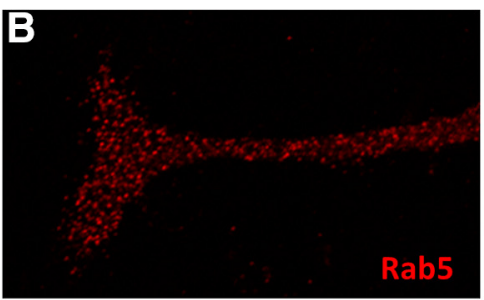

$\mathbf{F}$

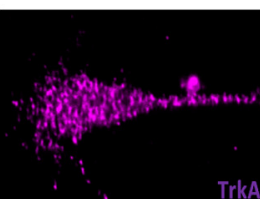

G

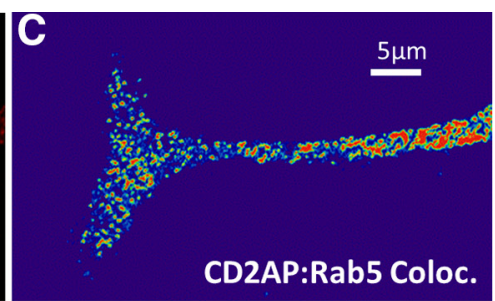

H
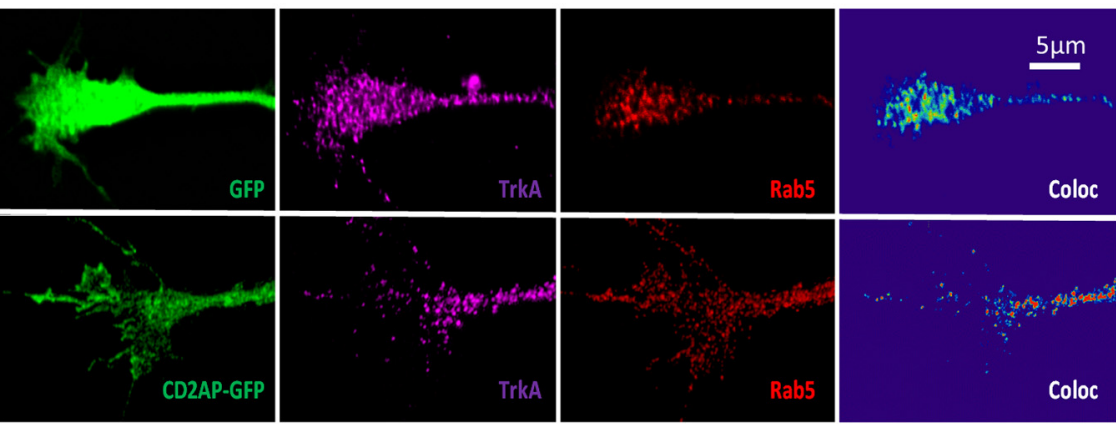

Figure 11. $C D 2 A P$ colocalizes with RAB5 in growth cones and is a positive regulator of TrkA recruitment into endosomes. Maximum-intensity projection of a representative growth cone stained to visualize $\operatorname{CD} 2 A P(A)$ and RAB5 $(\boldsymbol{B})$ and a $3 D$ colocalization heat map $(\boldsymbol{C}) . \boldsymbol{D}, \mathrm{CD} 2 \mathrm{AP}$ effect on TrkA recruitment to RAB5 ${ }^{+}$endosomes was quantified in growth cones following transfection either with GFP-CD2AP or with GFP control or following transfection either with CD2AP siRNA or with scramble control. Quantification was done on the ratio of GFP-CD2AP:GFP (0ver Exp.) and on the ratio of scramble:siCD2AP (siRNA). *Statistically significant changes compared with the respective control ( $\boldsymbol{t}$ test). $\boldsymbol{E}-\boldsymbol{H}$, Representative images from the $3 \mathrm{D}$ colocalization analyses from the overexpression experiment.
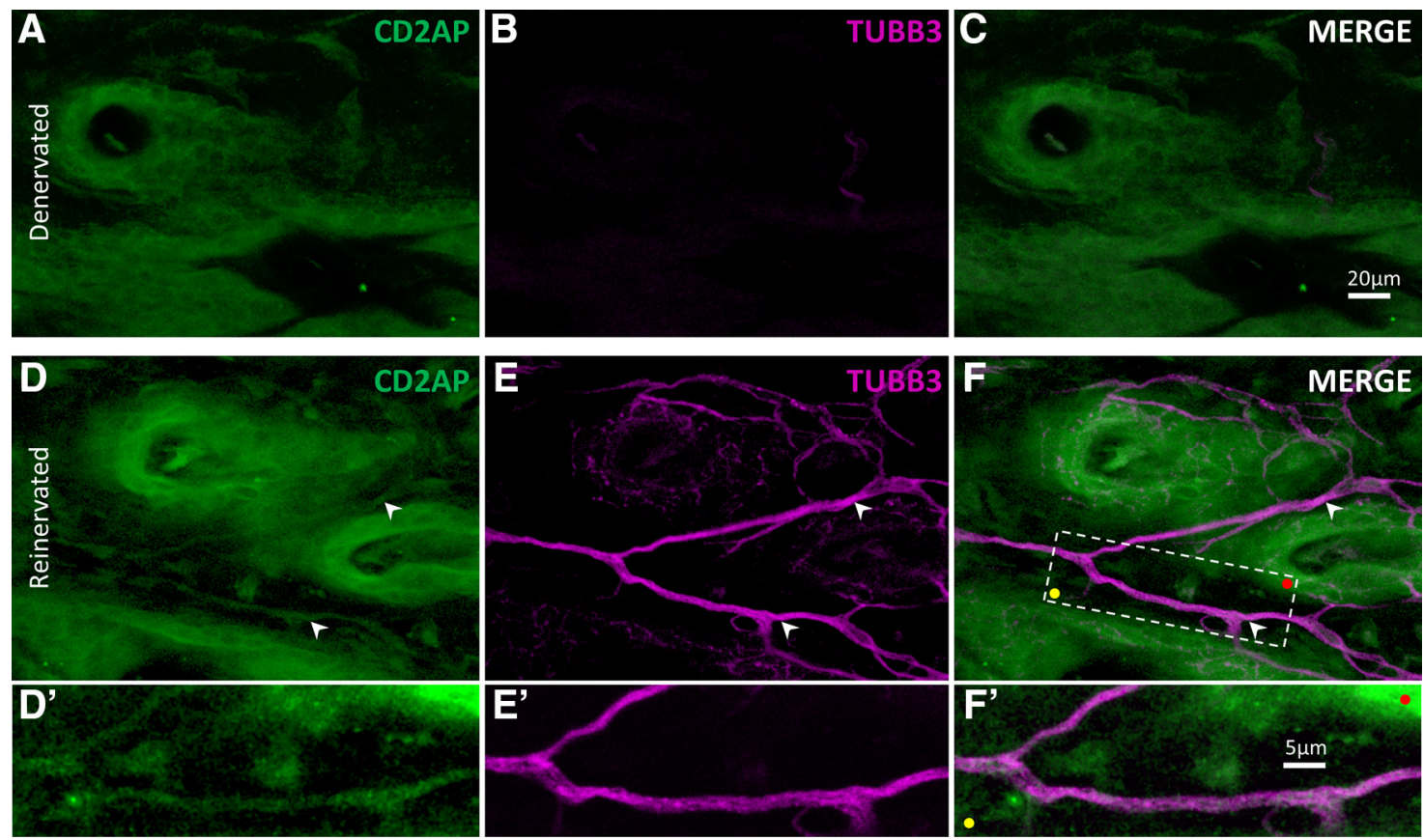

Figure 12. CD2AP is present in growing axons in reinnervated skin. Representative maximum-intensity projection through the epidermis of denervated $(\boldsymbol{A}-\boldsymbol{C})$, and adjacent collaterally reinnervated ( $\boldsymbol{D}-\boldsymbol{F})$ adult mouse dorsal skin, stained to visualize CD2AP (green) and neuron-specific tubulin (TUBB3; magenta). Skin was cleared using organic solvent to allow confocal imaging throughout the tissue in whole mount. Note the $\mathrm{CD}_{2} \mathrm{AP}^{+}$axons in reinnervating skin (white arrowheads). $\boldsymbol{F}$, Boxed area is shown in $\boldsymbol{D}^{\prime}-\boldsymbol{F}^{\prime}$. Colored dots indicate registration marks.

with RAB5-decorated endosomes. Our data, in conjunction with the literature, suggest that CD2AP may participate in directing intracellular signaling local to NGF:TrkA-binding, and also the sustained long-distance signaling mechanism, at least in PC12 cells, where CD2AP is a positive regulator of NGF signaling (Fig. 13).

Although it remains to be determined whether other trophic factors can regulate axonal arbor expansion in the spared der- matome model, it is known that NGF is required, but the intracellular mechanisms leading to axon growth are unclear. We have determined that CD2AP is a positive regulator of NGFstimulated PI3K/AKT signaling and associates with complexes containing the NGF receptor TrkA, and the $\mathrm{p} 85$ regulatory subunit of PI3K. Previous work shows that N-terminal SH3 domains of CD2AP can form complexes with p85 (Huber et al., 2003). 
TrkA also forms complexes with p85, but to our knowledge the nature of the p85: TrkA interaction is not well defined and may occur via an undefined adaptor protein (Vanhaesebroeck and Waterfield, 1999). Following NGF stimulation, p85 association with TrkA is regulated by levels of CD2AP (Fig. 10), suggesting that CD2AP could be an unidentified adaptor mediating p85:TrkA interaction (Fig. 13).

CD2AP regulates both AKT and MAPK/ ERK signaling in kidney podocytes (Table 1). Interestingly, we did not observe any regulatory effects of CD2AP levels on ERK signaling after $24 \mathrm{~h}$ of NGF stimulation. In many settings, the NGF-induced ERK and AKT cascades serve nonredundant functions. For example, in cultured DRG neurons, RAF overexpression (stimulating ERK) leads to production of elongated thin neurites, whereas AKT activity increases axon branching (Markus et al., 2002). In our model, NGF signaling may be directed by $\mathrm{CD} 2 \mathrm{AP}$ to activate the AKT pathway that may drive axon branch formation during arbor expansion. Accordingly, NGF promotes filopodia formation and axonal branching in a PI3K-dependent manner (Ketschek and Gallo, 2010) by inducing local actin nucleation by the Arp2/3 complex (Spillane et al., 2011). Independently, CD2AP has been shown to directly bind Arp2/3 to positively regulate actin nucleation and concomitant actin dynamics (Table 1). Also, CD2AP directly binds to Septin-7 and is a positive regulator of its assembly into filaments (Wasik et al., 2012), a process known to trigger filopodia formation during axonal branching ( $\mathrm{Hu}$ et al., 2012). Our data therefore suggest a role for CD2AP in driving trophic-factor-mediated actin dynamics, possibly via the AKT pathway, during axonal plasticity (Fig. 13).

AKT phosphorylates a diverse array of substrates, and the vast majority of evidence strongly suggests that it is a positive regulator of neurite growth (Read and Gorman, 2009; Miyamoto et al., 2013). It could occur, for example, by negative regulation of GSK3B or activation of mTOR (for review, see Read and Gorman, 2009). However, the downstream components linking AKT to axon growth are not well defined and may be context dependent. Interestingly, the only intracellular molecule identified as having a role in NGF-dependent collateral sprouting in the spared dermatome model, the intermediate filament protein peripherin (Belecky-Adams et al., 2003), is itself an AKT substrate (Konishi et al., 2007).

Targeting signaling regulators, such as CD2AP, may enable a more refined approach to therapies involving growth factor signaling than bulk approaches, such as antibody-based ligand sequestration. This strategy could provide much needed therapeutic interventions for the many disease states known to involve axonal plasticity: sensory neuropathies (Anand, 2004), autonomic dysreflexia after spinal cord injury (Rabchevsky, 2006), neuropathic pain (Khan and Smith, 2015), sudden cardiac death (Ieda and Fukuda, 2009), etc. CD2AP mutations, including one inducing an amino acid change in its coiled-coil domain (Vardarajan et al., 2015), are associated with late-onset Alzheimer's disease (Hollingworth et al., 2011; Naj et al., 2011). CD2AP can affect $\mathrm{A} \beta$ protein in neuroblastoma cells (Liao et al., 2015) and tau toxicity in Drosphila eyes (Shulman et al., 2014). This is particularly compelling considering that dysfunction of NGF signaling, axonal transport, and neural plasticity (Schindowski et al., 2008; Houeland et al., 2010; Niewiadomska et al., 2011) all contribute strongly to Alzheimer's disease. As succinctly stated by Cattaneo and Calissano (2012), “... a new NGF hypothesis can be built, with neurotrophic deficits of various types representing an upstream driver of the core $\mathrm{AD}$ triad pathology ... therapies aimed at reestablishing a correct homeostatic balance between ligands (and receptors) of the NGF pathway appear to have a clear and strong rationale...." Our data suggest that one might modify this to read: “. . . reestablishing a correct homeostatic balance between ligands, receptors, and signaling pathways induced by NGF ...," in considering possible mechanisms and therapies.

Interestingly, and perhaps very importantly, we observe that CD2AP is upregulated in DRGs during axonal sprouting (spared dermatome model) but downregulated during axonal regeneration. This difference highlights an important fact: the degree of similarity/difference in the intracellular molecular control of regeneration of injured axons and the collateral sprouting of noninjured axons remains an open question. This is understandable given the fact that genes regulating collateral sprouting are undoubtedly represented (although perhaps less prominently) in screens using models with mixed populations.

Many studies of adult axon growth regulators use cultured neurons, which are injured by the dissociation process. Although these models are enriched in that they include only injured neurons, they are limited for being in vitro. Others use nerve-injury models, predominantly sciatic nerve injury where the lumbar DRGs are then sampled for gene expression (Costigan et al., 2002; Stam et al., 2007; Mar et al., 2014). The DRGs contain both injured and noninjured neurons (e.g., neurons projecting into dorsal cutaneous nerves and the PBST muscle nerves). Still others use CNS conditions where neurons undergo axon growth but the 
injury status of the neurons is unclear (Li et al., 2010). Although successful for identifying regeneration-associated genes, mixed models are of unclear value for identifying genes regulating collateral sprouting. The magnitude of gene regulation appears much lower for collateral sprouting compared with injury/regeneration (Harrison et al., 2015). Thus, in models with mixed populations, the large changes in injured/regenerating neurons could easily overshadow changes in noninjured neurons. However, the genes expressed in those noninjured neurons would nonetheless be classified as "regeneration-associated genes" for their mere presence in the dataset. For this reason, it was vital to use a model with minimal contributions from injured/regenerating neurons as we did with the spared dermatome model, which led to our identification of CD2AP.

\section{References}

Adams B, Sazgar M, Osehobo P, Van der Zee CE, Diamond J, Fahnestock M, Racine RJ (1997) Nerve growth factor accelerates seizure development, enhances mossy fiber sprouting, and attenuates seizure-induced decreases in neuronal density in the kindling model of epilepsy. J Neurosci 17:5288-5296. Medline

Anand P (2004) Neurotrophic factors and their receptors in human sensory neuropathies. Prog Brain Res 146:477-492. CrossRef Medline

Baron R, Jänig W, With H (1995) Sympathetic and afferent neurones projecting into forelimb and trunk nerves and the anatomical organization of the thoracic sympathetic outflow of the rat. J Auton Nerv Syst 53:205-214. CrossRef Medline

Belecky-Adams T, Holmes M, Shan Y, Tedesco CS, Mascari C, Kaul A, Wight DC, Morris RE, Sussman M, Diamond J, Parysek LM (2003) An intact intermediate filament network is required for collateral sprouting of small diameter nerve fibers. J Neurosci 23:9312-9319. Medline

Blackmore MG, Wang Z, Lerch JK, Motti D, Zhang YP, Shields CB, Lee JK, Goldberg JL, Lemmon VP, Bixby JL (2012) Krüppel-like factor 7 engineered for transcriptional activation promotes axon regeneration in the adult corticospinal tract. Proc Natl Acad Sci U S A 109:7517-7522. CrossRef Medline

Bloom AP, Jimenez-Andrade JM, Taylor RN, Castañeda-Corral G, Kaczmarska MJ, Freeman KT, Coughlin KA, Ghilardi JR, Kuskowski MA, Mantyh PW (2011) Breast cancer-induced bone remodeling, skeletal pain, and sprouting of sensory nerve fibers. J Pain Off J Am Pain Soc 12:698-711. CrossRef Medline

Botchkarev VA, Eichmüller S, Johansson O, Paus R (1997) Hair cycledependent plasticity of skin and hair follicle innervation in normal murine skin. J Comp Neurol 386:379-395. CrossRef Medline

Calinescu AA, Liu T, Wang MM, Borjigin J (2011) Transsynaptic activitydependent regulation of axon branching and neurotrophin expression in vivo. J Neurosci 31:12708-12715. CrossRef Medline

Cattaneo A, Calissano P (2012) Nerve growth factor and Alzheimer's disease: new facts for an old hypothesis. Mol Neurobiol 46:588-604. CrossRef Medline

Chen Q, Zhou L, Shine HD (2006) Expression of neurotrophin-3 promotes axonal plasticity in the acute but not chronic injured spinal cord. J Neurotrauma 23:1254-1260. CrossRef Medline

Cheng JK, Ji RR (2008) Intracellular signaling in primary sensory neurons and persistent pain. Neurochem Res 33:1970-1978. CrossRef Medline

Cormont M, Metón I, Mari M, Monzo P, Keslair F, Gaskin C, McGraw TE, Le Marchand-Brustel Y (2003) CD2AP/CMS regulates endosome morphology and traffic to the degradative pathway through its interaction with Rab4 and c-Cbl. Traffic 4:97-112. CrossRef Medline

Costes SV, Daelemans D, Cho EH, Dobbin Z, Pavlakis G, Lockett S (2004) Automatic and quantitative measurement of protein protein colocalization in live cells. Biophys J 86:3993-4003. CrossRef Medline

Costigan M, Befort K, Karchewski L, Griffin RS, D’Urso D, Allchorne A, Sitarski J, Mannion JW, Pratt RE, Woolf CJ (2002) Replicate highdensity rat genome oligonucleotide microarrays reveal hundreds of regulated genes in the dorsal root ganglion after peripheral nerve injury. BMC Neurosci 3:16. CrossRef Medline

Davenport CJ, Brown WJ, Babb TL (1990) Sprouting of GABAergic and mossy fiber axons in dentate gyrus following intrahippocampal kainate in the rat. Exp Neurol 109:180-190. CrossRef Medline

Deinhardt K, Salinas S, Verastegui C, Watson R, Worth D, Hanrahan S, Bucci
C, Schiavo G (2006) Rab5 and Rab7 control endocytic sorting along the axonal retrograde transport pathway. Neuron 52:293-305. CrossRef Medline

Diamond J, Holmes M, Coughlin M (1992) Endogenous NGF and nerve impulses regulate the collateral sprouting of sensory axons in the skin of the adult rat. J Neurosci 12:1454-1466. Medline

Domchek SM, Auger KR, Chatterjee S, Burke TR Jr, Shoelson SE (1992) Inhibition of SH2 domain/phosphoprotein association by a nonhydrolyzable phosphonopeptide. Biochemistry 31:9865-9870. CrossRef Medline

Doron-Mandel E, Fainzilber M, Terenzio M (2015) Growth control mechanisms in neuronal regeneration. FEBS Lett 589:1669-1677. CrossRef Medline

Dustin ML, Olszowy MW, Holdorf AD, Li J, Bromley S, Desai N, Widder P, Rosenberger F, van der Merwe PA, Allen PM, Shaw AS (1998) A novel adaptor protein orchestrates receptor patterning and cytoskeletal polarity in T-cell contacts. Cell 94:667-677. CrossRef Medline

Eva R, Fawcett J (2014) Integrin signalling and traffic during axon growth and regeneration. Curr Opin Neurobiol 27:179-185. CrossRef Medline

Fagoe ND, van Heest J, Verhaagen J (2014) Spinal cord injury and the neuron-intrinsic regeneration-associated gene program. Neuromolecular Med 16:799-813. CrossRef Medline

Fawcett JW, Curt A, Steeves JD, Coleman WP, Tuszynski MH, Lammertse D, Bartlett PF, Blight AR, Dietz V, Ditunno J, Dobkin BH, Havton LA, Ellaway PH, Fehlings MG, Privat A, Grossman R, Guest JD, Kleitman N, Nakamura M, Gaviria M, et al. (2007) Guidelines for the conduct of clinical trials for spinal cord injury as developed by the ICCP panel: spontaneous recovery after spinal cord injury and statistical power needed for therapeutic clinical trials. Spinal Cord 45:190-205. CrossRef Medline

Georgieva MV, de Pablo Y, Sanchis D, Comella JX, Llovera M (2011) Ubiquitination of TrkA by Nedd $4-2$ regulates receptor lysosomal targeting and mediates receptor signaling. J Neurochem 117:479-493. CrossRef Medline

Gonzalez-Freire M, de Cabo R, Studenski SA, Ferrucci L (2014) The neuromuscular junction: aging at the crossroad between nerves and muscle. Front Aging Neurosci 6:208. CrossRef Medline

Greene LA, Tischler AS (1976) Establishment of a noradrenergic clonal line of rat adrenal pheochromocytoma cells which respond to nerve growth factor. Proc Natl Acad Sci U S A 73:2424-2428. CrossRef Medline

Grunkemeyer JA, Kwoh C, Huber TB, Shaw AS (2005) CD2-associated protein (CD2AP) expression in podocytes rescues lethality of CD2AP deficiency. J Biol Chem 280:29677-29681. CrossRef Medline

Harrison B, Kraus M, Burch L, Stevens C, Craig A, Gordon-Weeks P, Hupp TR (2008) DAPK-1 binding to a linear peptide motif in MAP1B stimulates autophagy and membrane blebbing. J Biol Chem 283:9999-10014. CrossRef Medline

Harrison BJ, Flight RM, Gomes C, Venkat G, Ellis SR, Sankar U, Twiss JL, Rouchka EC, Petruska JC (2014) IB4-binding sensory neurons in the adult rat express a novel $3^{\prime}$ UTR-extended isoform of CaMK4 that is associated with its localization to axons. J Comp Neurol 522:308-336. CrossRef Medline

Harrison BJ, Venkat G, Hutson T, Rau KK, Bunge MB, Mendell LM, Gage FH, Johnson RD, Hill C, Rouchka EC, Moon L, Petruska JC (2015) Transcriptional changes in sensory ganglia associated with primary afferent axon collateral sprouting in spared dermatome model. Genom Data 6:249-252. CrossRef Medline

Hill CE, Harrison BJ, Rau KK, Hougland MT, Bunge MB, Mendell LM, Petruska JC (2010) Skin incision induces expression of axonal regeneration-related genes in adult rat spinal sensory neurons. J Pain Off J Am Pain Soc 11:1066-1073. CrossRef Medline

Hollingworth P, Harold D, Sims R, Gerrish A, Lambert JC, Carrasquillo MM, Abraham R, Hamshere ML, Pahwa JS, Moskvina V, Dowzell K, Jones N, Stretton A, Thomas C, Richards A, Ivanov D, Widdowson C, Chapman J, Lovestone S, Powell J, et al. (2011) Common variants at ABCA7, MS4A6A/MS4A4E, EPHA1, CD33 and CD2AP are associated with Alzheimer's disease. Nat Genet 43:429-435. CrossRef Medline

Houeland G, Romani A, Marchetti C, Amato G, Capsoni S, Cattaneo A, Marie H (2010) Transgenic mice with chronic NGF deprivation and Alzheimer's disease-like pathology display hippocampal region-specific impairments in short- and long-term plasticities. J Neurosci 30:13089-13094. CrossRef Medline

Hsieh ST, Lin WM (1999) Modulation of keratinocyte proliferation by skin innervation. J Invest Dermatol 113:579-586. CrossRef Medline

Hsieh ST, Choi S, Lin WM, Chang YC, Mcarthur JC, Griffin JW (1996) 
Epidermal denervation and its effects on keratinocytes and Langerhans cells. J Neurocytol 25:513-524. CrossRef Medline

Hu J, Bai X, Bowen JR, Dolat L, Korobova F, Yu W, Baas PW, Svitkina T, Gallo G, Spiliotis ET (2012) Septin-driven coordination of actin and microtubule remodeling regulates the collateral branching of axons. Curr Biol 22:1109-1115. CrossRef Medline

Huber TB, Hartleben B, Kim J, Schmidts M, Schermer B, Keil A, Egger L, Lecha RL, Borner C, Pavenstädt H, Shaw AS, Walz G, Benzing T (2003) Nephrin and CD2AP associate with phosphoinositide 3-OH kinase and stimulate AKT-dependent signaling. Mol Cell Biol 23:4917-4928. CrossRef Medline

Hutson TH, Buchser WJ, Bixby JL, Lemmon VP, Moon LD (2011) Optimization of a 96-well electroporation assay for postnatal rat CNS neurons suitable for cost-effective medium-throughput screening of genes that promote neurite outgrowth. Front Mol Neurosci 4:55. CrossRef Medline

Iarikov DE, Kim BG, Dai HN, McAtee M, Kuhn PL, Bregman BS (2007) Delayed transplantation with exogenous neurotrophin administration enhances plasticity of corticofugal projections after spinal cord injury. J Neurotrauma 24:690-702. CrossRef Medline

Ibrahim Z, Ebenezer G, Christensen JM, Sarhane KA, Hauer P, Cooney DS, Sacks JM, Schneeberger S, Lee WP, Polydefkis M, Brandacher G (2013) Cutaneous collateral axonal sprouting reinnervates the skin component and restores sensation of denervated Swine osteomyocutaneous alloflaps. PLoS One 8:e77646. CrossRef Medline

Ieda M, Fukuda K (2009) Cardiac innervation and sudden cardiac death. Curr Cardiol Rev 5:289-295. CrossRef Medline

Jimenez-Andrade JM, Bloom AP, Stake JI, Mantyh WG, Taylor RN, Freeman KT, Ghilardi JR, Kuskowski MA, Mantyh PW (2010) Pathological sprouting of adult nociceptors in chronic prostate cancer-induced bone pain. J Neurosci 30:14649-14656. CrossRef Medline

Jimenez-Andrade JM, Ghilardi JR, Castañeda-Corral G, Kuskowski MA, Mantyh PW (2011) Preventive or late administration of anti-NGF therapy attenuates tumor-induced nerve sprouting, neuroma formation, and cancer pain. Pain 152:2564-2574. CrossRef Medline

Johnson RI, Seppa MJ, Cagan RL (2008) The Drosophila CD2AP/CIN85 orthologue Cindr regulates junctions and cytoskeleton dynamics during tissue patterning. J Cell Biol 180:1191-1204. CrossRef Medline

Kawabuchi M, Zhou C, Nakamura K, Hirata K (1995) Morphological features of collateral innervation and supernumerary innervation in the skeletal muscles of presenile rats. Ann Anat 177:251-265. CrossRef Medline

Ketschek A, Gallo G (2010) Nerve growth factor induces axonal filopodia through localized microdomains of phosphoinositide 3-kinase activity that drive the formation of cytoskeletal precursors to filopodia. J Neurosci 30:12185-12197. CrossRef Medline

Khan N, Smith MT (2015) Neurotrophins and neuropathic pain: role in pathobiology. Molecules 20:10657-10688. CrossRef Medline

Kim JM, Wu H, Green G, Winkler CA, Kopp JB, Miner JH, Unanue ER, Shaw AS (2003) CD2-associated protein haploinsufficiency is linked to glomerular disease susceptibility. Science 300:1298-1300. CrossRef Medline

Kirsch KH, Georgescu MM, Ishimaru S, Hanafusa H (1999) CMS: an adapter molecule involved in cytoskeletal rearrangements. Proc Natl Acad Sci U S A 96:6211-6216. CrossRef Medline

Kobayashi S, Sawano A, Nojima Y, Shibuya M, Maru Y (2004) The c-Cbl/ CD2AP complex regulates VEGF-induced endocytosis and degradation of Flt-1 (VEGFR-1). FASEB J 18:929-931. CrossRef Medline

Konishi H, Namikawa K, Shikata K, Kobatake Y, Tachibana T, Kiyama H (2007) Identification of peripherin as a Akt substrate in neurons. J Biol Chem 282:23491-23499. CrossRef Medline

Krenz NR, Meakin SO, Krassioukov AV, Weaver LC (1999) Neutralizing intraspinal nerve growth factor blocks autonomic dysreflexia caused by spinal cord injury. J Neurosci 19:7405-7414. Medline

Lehtonen S, Tienari J, Londesborough A, Pirvola U, Ora A, Reima I, Lehtonen E (2008) CD2-associated protein is widely expressed and differentially regulated during embryonic development. Differentiation 76:506-517. CrossRef Medline

Lei L, Laub F, Lush M, Romero M, Zhou J, Luikart B, Klesse L, Ramirez F, Parada LF (2005) The zinc finger transcription factor Klf7 is required for TrkA gene expression and development of nociceptive sensory neurons. Genes Dev 19:1354-1364. CrossRef Medline

Li L, Rutlin M, Abraira VE, Cassidy C, Kus L, Gong S, Jankowski MP, Luo W, Heintz N, Koerber HR, Woodbury CJ, Ginty DD (2011) The functional organization of cutaneous low-threshold mechanosensory neurons. Cell 147:1615-1627. CrossRef Medline

Liao F, Jiang H, Srivatsan S, Xiao Q, Lefton KB, Yamada K, Mahan TE, Lee JM, Shaw AS, Holtzman DM (2015) Effects of CD2-associated protein deficiency on amyloid- $\beta$ in neuroblastoma cells and in an APP transgenic mouse model. Mol Neurodegener 10:12. CrossRef Medline

Li S, Overman JJ, Katsman D, Kozlov SV, Donnelly CJ, Twiss JL, Giger RJ, Coppola G, Geschwind DH, Carmichael ST (2010) An age-related sprouting transcriptome provides molecular control of axonal sprouting after stroke. Nat Neurosci 13:1496-1504. CrossRef Medline

Li Y, Hsieh ST, Chien HF, Zhang X, McArthur JC, Griffin JW (1997) Sensory and motor denervation influence epidermal thickness in rat foot glabrous skin. Exp Neurol 147:452-462. CrossRef Medline

Limpert AS, Karlo JC, Landreth GE (2007) Nerve growth factor stimulates the concentration of TrkA within lipid rafts and extracellular signalregulated kinase activation through $\mathrm{c}-\mathrm{Cbl}$-associated protein. Mol Cell Biol 27:5686-5698. CrossRef Medline

López-Álvarez VM, Modol L, Navarro X, Cobianchi S (2015) Early increasing-intensity treadmill exercise reduces neuropathic pain by preventing nociceptor collateral sprouting and disruption of chloride cotransporters homeostasis after peripheral nerve injury. Pain 156: 1812-1825. CrossRef Medline

Lynch DK, Winata SC, Lyons RJ, Hughes WE, Lehrbach GM, Wasinger V, Corthals G, Cordwell S, Daly RJ (2003) A Cortactin-CD2-associated protein (CD2AP) complex provides a novel link between epidermal growth factor receptor endocytosis and the actin cytoskeleton. J Biol Chem 278:21805-21813. CrossRef Medline

Mar FM, Bonni A, Sousa MM (2014) Cell intrinsic control of axon regeneration. EMBO Rep 15:254-263. CrossRef Medline

Markus A, Zhong J, Snider WD (2002) Raf and Akt mediate distinct aspects of sensory axon growth. Neuron 35:65-76. CrossRef Medline

Marsh DR, Wong ST, Meakin SO, MacDonald JI, Hamilton EF, Weaver LC (2002) Neutralizing intraspinal nerve growth factor with a trkA-IgG fusion protein blocks the development of autonomic dysreflexia in a clipcompression model of spinal cord injury. J Neurotrauma 19:1531-1541. CrossRef Medline

Marshall CJ (1995) Specificity of receptor tyrosine kinase signaling: transient versus sustained extracellular signal-regulated kinase activation. Cell 80:179-185. CrossRef Medline

Matusica D, Coulson EJ (2014) Local versus long-range neurotrophin receptor signalling: endosomes are not just carriers for axonal transport. Semin Cell Dev Biol 31:57-63. CrossRef Medline

Maysinger D, Holmes M, Han X, Epand RM, Pertens E, Foerster A, Barlas C, Holtzman DM, Diamond J (2008) Ceramide is responsible for the failure of compensatory nerve sprouting in apolipoprotein E knock-out mice. J Neurosci 28:7891-7899. CrossRef Medline

Miyamoto Y, Torii T, Yamamori N, Ogata T, Tanoue A, Yamauchi J (2013) Akt and PP2A reciprocally regulate the guanine nucleotide exchange factor Dock6 to control axon growth of sensory neurons. Sci Signal 6:ra15. CrossRef Medline

Naj AC, Jun G, Beecham GW, Wang LS, Vardarajan BN, Buros J, Gallins PJ, Buxbaum JD, Jarvik GP, Crane PK, Larson EB, Bird TD, Boeve BF, GraffRadford NR, De Jager PL, Evans D, Schneider JA, Carrasquillo MM, Ertekin-Taner N, Younkin SG, et al. (2011) Common variants at MS4A4/MS4A6E, CD2AP, CD33 and EPHA1 are associated with lateonset Alzheimer's disease. Nat Genet 43:436-441. CrossRef Medline

Niewiadomska G, Mietelska-Porowska A, Mazurkiewicz M (2011) The cholinergic system, nerve growth factor and the cytoskeleton. Behav Brain Res 221:515-526. CrossRef Medline

Noebels JL (1984) A single gene error of noradrenergic axon growth synchronizes central neurones. Nature 310:409-411. CrossRef Medline

Pertens E, Urschel-Gysbers BA, Holmes M, Pal R, Foerster A, Kril Y, Diamond J (1999) Intraspinal and behavioral consequences of nerve growth factor-induced nociceptive sprouting and nerve growth factorinduced hyperalgesia compared in adult rats. J Comp Neurol 410:73-89. CrossRef Medline

Petruska JC, Mendell LM (2004) The many functions of nerve growth factor: multiple actions on nociceptors. Neurosci Lett 361:168-171. CrossRef Medline

Petruska JC, Barker DF, Garraway SM, Trainer R, Fransen JW, Seidman PA, Soto RG, Mendell LM, Johnson RD (2014) Organization of sensory input to the nociceptive-specific cutaneous trunk muscle reflex in rat, an 
effective experimental system for examining nociception and plasticity. J Comp Neurol 522:1048-1071. CrossRef Medline

Pitkänen A, Sutula TP (2002) Is epilepsy a progressive disorder? Prospects for new therapeutic approaches in temporal-lobe epilepsy. Lancet Neurol 1:173-181. CrossRef Medline

Prince DA, Parada I, Scalise K, Graber K, Jin X, Shen F (2009) Epilepsy following cortical injury: cellular and molecular mechanisms as targets for potential prophylaxis. Epilepsia 50 [Suppl 2]:30-40.

Rabchevsky AG (2006) Segmental organization of spinal reflexes mediating autonomic dysreflexia after spinal cord injury. Prog Brain Res 152:265274. CrossRef Medline

Read DE, Gorman AM (2009) Involvement of Akt in neurite outgrowth. Cell Mol Life Sci 66:2975-2984. CrossRef Medline

Rosenzweig ES, Courtine G, Jindrich DL, Brock JH, Ferguson AR, Strand SC, Nout YS, Roy RR, Miller DM, Beattie MS, Havton LA, Bresnahan JC, Edgerton VR, Tuszynski MH (2010) Extensive spontaneous plasticity of corticospinal projections after primate spinal cord injury. Nat Neurosci 13:1505-1510. CrossRef Medline

Scharfman HE, Goodman JH, Sollas AL (1999) Actions of brain-derived neurotrophic factor in slices from rats with spontaneous seizures and mossy fiber sprouting in the dentate gyrus. J Neurosci 19:5619-5631. Medline

Schindowski K, Belarbi K, Buée L (2008) Neurotrophic factors in Alzheimer's disease: role of axonal transport. Genes Brain Behav 7 [Suppl 1]: 43-56.

Schneider CA, Rasband WS, Eliceiri KW (2012) NIH Image to ImageJ: 25 years of image analysis. Nat Methods 9:671-675. CrossRef Medline

Selim MM, Wabner KA, Wendelschafer-Crabb G, Kennedy WR (2007) Stimulated growth of human and pig epidermal nerve fibers by tape stripping. Arch Dermatol Res 299:513-516. CrossRef Medline

Sholl DA (1953) Dendritic organization in the neurons of the visual and motor cortices of the cat. J Anat 87:387-406. Medline

Shulman JM, Imboywa S, Giagtzoglou N, Powers MP, Hu Y, Devenport D, Chipendo P, Chibnik LB, Diamond A, Perrimon N, Brown NH, De Jager PL, Feany MB (2014) Functional screening in Drosophila identifies Alzheimer's disease susceptibility genes and implicates Tau-mediated mechanisms. Hum Mol Genet 23:870-877. CrossRef Medline

Sierra A, Gröhn O, Pitkänen A (2015) Imaging microstructural damage and plasticity in the hippocampus during epileptogenesis. Neuroscience 309: 162-172. CrossRef Medline

Spillane M, Ketschek A, Jones SL, Korobova F, Marsick B, Lanier L, Svitkina T, Gallo G (2011) The actin nucleating Arp2/3 complex contributes to the formation of axonal filopodia and branches through the regulation of actin patch precursors to filopodia. Dev Neurobiol 71:747-758. CrossRef Medline

Stam FJ, MacGillavry HD, Armstrong NJ, de Gunst MC, Zhang Y, van Kesteren RE, Smit AB, Verhaagen J (2007) Identification of candidate transcriptional modulators involved in successful regeneration after nerve injury. Eur J Neurosci 25:3629-3637. CrossRef Medline

Stenmark H (2009) Rab GTPases as coordinators of vesicle traffic. Nat Rev Mol Cell Biol 10:513-525. CrossRef Medline

Tang VW, Brieher WM (2013) FSGS3/CD2AP is a barbed-end capping protein that stabilizes actin and strengthens adherens junctions. J Cell Biol 203:815-833. CrossRef Medline

Tavosanis G (2012) Dendritic structural plasticity. Dev Neurobiol 72: 73-86. CrossRef Medline

Tossidou I, Kardinal C, Peters I, Kriz W, Shaw A, Dikic I, Tkachuk S, Dumler
I, Haller H, Schiffer M (2007) CD2AP/CIN85 balance determines receptor tyrosine kinase signaling response in podocytes. J Biol Chem 282: 7457-7464. CrossRef Medline

Tsui CC, Pierchala BA (2008) CD2AP and Cbl-3/Cbl-c constitute a critical checkpoint in the regulation of ret signal transduction. J Neurosci 28: 8789-8800. CrossRef Medline

Van der Zee CE, Rashid K, Le K, Moore KA, Stanisz J, Diamond J, Racine RJ, Fahnestock M (1995) Intraventricular administration of antibodies to nerve growth factor retards kindling and blocks mossy fiber sprouting in adult rats. J Neurosci 15:5316-5323. Medline

Vanhaesebroeck B, Waterfield MD (1999) Signaling by distinct classes of phosphoinositide 3-kinases. Exp Cell Res 253:239-254. CrossRef Medline

Vardarajan BN, Ghani M, Kahn A, Sheikh S, Sato C, Barral S, Lee JH, Cheng R, Reitz C, Lantigua R, Reyes-Dumeyer D, Medrano M, JimenezVelazquez IZ, Rogaeva E, St George-Hyslop P, Mayeux R (2015) Rare coding mutations identified by sequencing of Alzheimer's disease GWAS loci. Ann Neurol 78:487-498. CrossRef Medline

Vaseghi M, Shivkumar K (2008) The role of the autonomic nervous system in sudden cardiac death. Prog Cardiovasc Dis 50:404-419. CrossRef Medline

Wanigasekara Y, Keast JR (2006) Nerve growth factor, glial cell line-derived neurotrophic factor and neurturin prevent semaphorin 3A-mediated growth cone collapse in adult sensory neurons. Neuroscience 142: 369-379. CrossRef Medline

Wasik AA, Polianskyte-Prause Z, Dong MQ, Shaw AS, Yates JR 3rd, Farquhar MG, Lehtonen S (2012) Septin 7 forms a complex with CD2AP and nephrin and regulates glucose transporter trafficking. Mol Biol Cell 23: 3370-3379. CrossRef Medline

Welsch T, Endlich N, Gökce G, Doroshenko E, Simpson JC, Kriz W, Shaw AS, Endlich K (2005) Association of CD2AP with dynamic actin on vesicles in podocytes. Am J Physiol Renal Physiol 289:F1134-F1143. CrossRef Medline

Woolf CJ (1996) Phenotypic modification of primary sensory neurons: the role of nerve growth factor in the production of persistent pain. Philos Trans R Soc Lond B Biol Sci 351:441-448. CrossRef Medline

Wu H, Williams J, Nathans J (2014) Complete morphologies of basal forebrain cholinergic neurons in the mouse. eLife 3:e02444. CrossRef Medline

Yaddanapudi S, Altintas MM, Kistler AD, Fernandez I, Möller CC, Wei C, Peev V, Flesche JB, Forst AL, Li J, Patrakka J, Xiao Z, Grahammer F, Schiffer M, Lohmüller T, Reinheckel T, Gu C, Huber TB, Ju W, Bitzer M, et al. (2011) CD2AP in mouse and human podocytes controls a proteolytic program that regulates cytoskeletal structure and cellular survival. J Clin Invest 121:3965-3980. CrossRef Medline

Yasuda M, Johnson-Venkatesh EM, Zhang H, Parent JM, Sutton MA, Umemori H (2011) Multiple forms of activity-dependent competition refine hippocampal circuits in vivo. Neuron 70:1128-1142. CrossRef Medline

Ygge J (1984) On the organization of the thoracic spinal ganglion and nerve in the rat. Exp Brain Res 55:395-401. Medline

Zhao J, Bruck S, Cemerski S, Zhang L, Butler B, Dani A, Cooper JA, Shaw AS (2013) CD2AP links cortactin and capping protein at the cell periphery to facilitate formation of lamellipodia. Mol Cell Biol 33:38-47. CrossRef Medline

Zhou S, Chen LS, Miyauchi Y, Miyauchi M, Kar S, Kangavari S, Fishbein MC, Sharifi B, Chen PS (2004) Mechanisms of cardiac nerve sprouting after myocardial infarction in dogs. Circ Res 95:76-83. CrossRef Medline 